MENS \& MAATSCHAPPIJ

www.mensenmaatschappij.nl

Uitgave: Amsterdam University Press

\title{
Op rozen zitten, of op zwart zaad
}

Twee decennia inkomensongelijkheid

Cok Vrooman \& Jean Marie Wildeboer Schut

MEM 90 (4): 343-378

DOI: 10.5117/MEM2015.3.VROO

\section{Summary}

A cushy life, or being dead broke: Two decades of income inequality

Did income inequality decrease since the 1990s due to less pronounced differentials in educational attainment among the Dutch population, as modernisation theory presumes? Have the growing labour participation of women and the ensuing demise of the one-earner family translated into greater income disparities? And has public support for income redistribution dwindled? Various measures calculated over the tax data from the Income Panel Survey show that income inequality did not become less in the Netherlands, but grew somewhat, especially since 2001. This is most clearly the case with regard to earned income, and less so for gross income. During the new millennium the weakest growth occurred in the inequality of disposable income, and here the overall picture since 1990 is fairly stable. A decomposition analysis indicates that changes in educational attainment and in the average incomes of the lower, middle and higher educated hardly affected income inequality over time. The same applies to the rise in the number of people of non-western origin and the altering income levels of ethnic groups. Changes in the number of earners per household, however, did alter income inequality. The rising share of comparatively poor single persons saw their average income deteriorate in the 2000s, while the affluent group of double earners grew in size and generally experienced further income improvement. Over time, couples depending on one income became a rather small category, and their average amount of income decreased. Yet changes in people's income sources were more important. This especially concerns the inequality enhancing effect of the growth in the relative number of pensioners and self-employed in the 2000s, vis-à-vis the dwindling share of employees. However, this was mitigated by higher average pensions among 
the elderly and lower incomes of entrepreneurs. In public opinion 1991 proved to be a turning point: The trend towards ever lower support for the redistribution of income that prevailed in the 1970s and 1980s reversed.

Keywords: income inequality, poverty, wealth, public opinion, decomposition

\section{$1 \quad$ Inleiding}

Nadat het thema lange tijd minder aandacht kreeg staat economische ongelijkheid de laatste jaren weer in het brandpunt van het politieke en wetenschappelijke debat. De langdurige recessie heeft dit in de hand gewerkt, mogelijk versterkt door falende instituties (Stiglitz, 2012); en de Engelse vertaling van Piketty's Le Capital au XXIe siècle (2014) joeg de discussie wereldwijd aan. In Nederland stelde de Wetenschappelijke Raad voor het Regeringsbeleid een bundel over inkomens- en vermogensongelijkheid samen, met bijdragen van externe auteurs (Kremer e.a., 2014). Salverda (2014) concludeerde hierin - op basis van een eigen bewerking van CBS-tabellen - dat de inkomensongelijkheid in Nederland de laatste decennia 'drastisch' was gegroeid. ${ }^{1}$ Hij schreef die ontwikkeling toe aan een aantal veranderingen: meer en hogere topinkomens; lagere uitkeringen; meer ouderen die vaker over een aanvullend pensioen beschikken en daardoor uit het laagste deciel verdwijnen; en een toename van de groep hogere middeninkomens als gevolg van het groeiend aandeel tweeverdieners. Via de veelgebruikte Ginicoëfficiënt zouden deze trends onvoldoende worden waargenomen (zie ook Salverda e.a., 2013; Salverda, 2013). ${ }^{2}$ In dezelfde bundel wees De Beer (2014) op groeiende beloningsverschillen bij voltijdwerknemers (al stopte die trend na 2006), vooral door de stagnerende loonontwikkeling aan de onderkant van de arbeidsmarkt, met inbegrip van het minimumloon. Volgens hem bevordert de groei van het aantal deeltijdarbeiders, met verhoudingsgewijs grote tegenstellingen in uurloon, eveneens de toename in loonverschillen. De ongelijkheid in financieel vermogen is volgens Van Bavel (2014) - die zich onder andere baseert op gegevens uit de Quote 500 - eveneens behoorlijk toegenomen: waar de allerrijkste groep in 1997 over zes procent van het totale vermogen beschikte, was dat in 2010 opgelopen tot tien procent. De WRR verbond aan deze drie bijdragen de conclusie dat de inkomensongelijkheid in Nederland naar internationale maatstaven door de uitgebreide verzorgingsstaat beperkt is, maar sinds het midden van de jaren tachtig wel toenam; en dat de vermogensongelijkheid in vergelijking met andere landen groot is, en 
eveneens oploopt. De uitspraak 'de armen worden armer en de rijken worden rijker' is volgens de Raad dan ook van toepassing op Nederland (Kremer e.a., 2014: 16). Daarom vindt de WRR het wenselijk bestaande herverdelingsmechanismen te moderniseren, om nieuwe kwetsbare groepen (zoals eenverdieners en de groeiende groepen flexwerkers en ZZP'ers) en de middenklassen beter te beschermen. Daarnaast opperde de Raad, in navolging van Hacker (2011), dat er meer 'predistributief beleid zou kunnen worden gevoerd. Hierbij dacht men niet uitsluitend aan klassieke collectieve regels - een hoger minimumloon, cao-afspraken over de verhouding tussen de laagste en de hoogste inkomens in bedrijven - maar ook aan nieuwe middelen, zoals het uitoefenen van consumentendruk op bedrijven met een te groot geachte loonkloof. Op basis van een historische landenvergelijking beval ook Atkinson (2015) onlangs aan de wereldwijde trend naar meer economische ongelijkheid aan te pakken.

Er klinken echter ook andere geluiden. Het CBS (2014) neemt in Nederland geen substantiële stijging in de inkomensongelijkheid waar, evenmin als Caminada e.a. (2014a, 2015). In de naoorlogse periode was volgens deze bronnen sprake van een gestage daling, met een korte toename vanaf het midden van de jaren tachtig. Daarna bleef het beeld goeddeels stabiel (zie ook Van den Berg \& Hartog, 1999; Hartog \& Veenbergen, 1978). Ten aanzien van de ongelijkheid in financieel vermogen was volgens verscheidene auteurs na de Tweede Wereldoorlog tot 1975 eveneens sprake van een voortdurende afname, en trad in de laatste decennia stabilisering op (Caminada e.a., 2014b; CBS, 2014; Roine \& Wälderström, 2014; Wilterdink, 1984). Sinds 2006 zijn de vermogensverschillen volgens het CBS weliswaar iets opgelopen, maar dat houdt verband met een groter aandeel negatieve vermogens door de dalende huizenprijzen (CBS, 2014; Pouwel-Urlings \& Van den Brakel, 2014). In het Sociaal en Cultureel Rapport 2014 concludeerde het Sociaal en Cultureel Planbureau (SCP) dat financiële tegenstellingen in Nederland voor het beleid een minder urgent aspect van sociale ongelijkheid zijn (Vrooman e.a., 2014).

De verwachtingen uit de WRR-studie van twintig jaar geleden (Ganzeboom \& Ultee, 1996), die in deze editie van Mens \& Maatschappij opnieuw worden bezien, hadden geen betrekking op vermogensverschillen, maar op de destijds verwachte inkomensongelijkheid. Om die reden beperken wij ons daar in deze bijdrage eveneens toe. Wat waren de toenmalige voorspellingen over de ontwikkeling van de inkomensongelijkheid tot 2015, en zijn ze uitgekomen? In hun inleiding spraken de redacteuren destijds één tamelijk veilige verwachting uit: 'koopkrachtplaatjes of versies hiervan zullen ... in 2015 op de derde dinsdag in september veel aandacht krijgen' 
(Ganzeboom \& Ultee, 1996: 8). Dit was echter niet omdat zij zelf destijds de inkomenstegenstellingen de belangrijkste maatschappelijke scheidslijn vonden. Op grond van de moderniseringstheorie achtten de auteurs de technologische ontwikkeling bepalend. Die had in de $20^{\mathrm{e}}$ eeuw gezorgd voor een gestage toename van de welvaart, die samenging met de onderwijsexpansie, meritocratisering, schaalvergroting, toenemende ruimtelijke mobiliteit en urbanisatie (zie ook Dronkers \& Ultee, 1995). Van de grotere welvaart profiteerden alle werkenden, en daardoor werd de economische ongelijkheid in de loop der tijd kleiner. De gegroeide welvaart maakte het bovendien mogelijk publieke voorzieningen te treffen waar werklozen en andere burgers baat bij hadden (uitkeringen, AOW, gezondheidszorg, onderwijs). Ook dat leidde tot ongelijkheidsreductie, en zorgde er tevens voor dat de leefsituatie van de Nederlandse bevolking verbeterde en sociale spanningen afnamen. De technologische ontwikkeling had volgens Ganzeboom en Ultee tegelijkertijd de resterende opleidingsverschillen tot de overheersende factor van de sociale segmentatie gemaakt. De hogere stand van de technologie vereiste immers steeds meer kennis, en een groeiende kloof in de levenskansen van hoog- en laagopgeleiden lag dan ook voor de hand: de laatsten beschikten steeds minder over de inzichten en vaardigheden die nodig zijn om maatschappelijk mee te komen. Dit is in lijn met de destijds onder economen gangbare hypothese over de arbeidsmarkt- en inkomenseffecten van skill biased technological change (Katz \& Murphy, 1992). Die betreffen groeiende loontegenstellingen tussen hoogen laagopgeleiden, omdat de eerste groep een sterkere productiviteitsstijging realiseert door de opkomst van nieuwe (informatie)technologie. De recent populaire veronderstelling van routine biased technological change werd destijds nog niet gemaakt. Volgens die notie komt juist de arbeidsmarkt- en inkomenspositie van middelbaar opgeleiden onder druk te staan, vanwege robotisering en automatisering van routinetaken, ook in de dienstensector (bijvoorbeeld Autor \& Dorn, 2013; De Graaf-Zijl e.a., 2015). Wel merkten Ganzeboom en Ultee op dat het arbeidsmarktperspectief minder gunstig zou worden voor hoger opgeleiden met een studierichting die slecht aansluit bij de technologische vernieuwing. Veranderingen in het beroepsniveau waren volgens hen minder relevant dan die in het onderwijs. Al was het in veel sociologisch onderzoek destijds een centrale variabele, de arbeidsmarkt was niet meer dan de schakel die 'diploma's het meest converteert in beschikbaar inkomen' (Ganzeboom \& Ultee 1996: 9). Inkomensongelijkheid is in deze visie uiteindelijk een afgeleide van de opleidingsverschillen, waarvan ook allerlei andere levensterreinen (ge- 
zondheid, opvattingen, leefstijl, partnerselectie) door technologische veranderingen en het bredere moderniseringsproces doordrenkt geraken.

Ganzeboom en Ultee (1996) verwachtten dat de trend naar geringer inkomensverschillen tot 2015 zou aanhouden, juist omdat de contrasten naar opleiding bij de nieuwe generaties nog kleiner zouden worden. Zij wezen echter ook op ontwikkelingen die ervoor konden zorgen dat deze hoofdhypothese verworpen zou moeten worden:

- Een instroom van migranten met lage onderwijskwalificaties kon ervoor zorgen dat de verschillen naar opleiding niet verder zouden afnemen, en de inkomensongelijkheid dus evenmin.

- Flexibilisering van de arbeidsmarkt kon leiden tot meer inkomensongelijkheid, al achtte men het denkbaar dat sterke vakbonden het tij zouden doen keren.

- Indien inkomens zouden worden vrijgegeven kon dat, gezien de toenmalige ervaringen in het Verenigd Koninkrijk, gepaard gaan met sterk groeiende topinkomens, waarbij de beloning in geen verhouding staat tot de geleverde prestaties. De toenemende ongelijkheid aan de bovenkant zou vervolgens kunnen leiden tot een roep om een 'wanprestatiebestraffing', hetgeen de ontwikkeling weer kon remmen.

- Wanneer de koopkrachtontwikkeling langdurig zou achterblijven, zou de opleidingshomogamie kunnen toenemen, en daarmee ook de inkomensongelijkheid. Omdat heterogamie tot op zekere hoogte een luxegoed is, wordt het in slechte tijden theoretisch waarschijnlijker dat men binnen de eigen welstandskring trouwt. Het verleden leerde echter dat dit niet vanzelf spreekt: historisch vertoonde de opleidingshomogamie in de praktijk vrij onduidelijke schommelingen.

Over de verwachte effecten die deze ontwikkelingen per saldo op de inkomensongelijkheid tot 2015 zouden hebben spraken Ganzeboom en Ultee (1996) zich niet uit. Dessens (1996) ging in de WRR-studie wel uitgebreid in op mogelijke gevolgen van een groeiende arbeidsdeelname van vrouwen. Hij verrichtte daartoe een aantal simulaties op het looninkomen en het bruto inkomen (loon plus overdrachtsuitkeringen) van partners. Daarbij baseerde hij zich op de enquêtegegevens uit het Aanvullend Voorzieningengebruikonderzoek (AVO) van het SCP, en ontwikkelde een prognose voor 1991-2011. Zijn voornaamste conclusie was dat de ongelijkheid in huishoudensinkomens in die periode door de groeiende arbeidsdeelname van vrouwen met 15 procent zou toenemen: de Ginicoëfficiënt zou bij (echt) paren oplopen van 0,33 tot 0,38 . Dit kon echter worden getemperd wan- 
neer de beloningsverschillen tussen mannen en vrouwen af zouden nemen.

Hermkens (1996) analyseerde destijds de veranderende inkomenspreferenties van de bevolking. Terugkijkend naar de periode 1975-1994 zag hij op basis van de gegevens uit Culturele Veranderingen in Nederland onder andere de steun voor inkomensnivellering gestaag afnemen. Die trend was volgens hem autonoom: ze hing niet samen met veranderingen naar opleiding, inkomenspeil, geslacht of politieke oriëntatie. Omdat het causale mechanisme onduidelijk was, waagde Hermkens zich niet aan een vooruitberekening over de inkomensoordelen. Een simpele lineaire-regressieanalyse op basis van de door hem gepresenteerde gegevens (Hermkens, 1996: 315) leert echter dat de trendmatige daling in de door hem onderzochte periode jaarlijks 1 à 1,5 procentpunt bedroeg. ${ }^{3}$ Als we op basis daarvan een conservatieve vooruitberekening maken, zou het aandeel mensen dat nivellering voorstaat tussen 1994 en 2012 met twee vijfde moeten afnemen (van 49 naar 29 procent). In 1980, het hoogtepunt in de tijdreeks die Hermkens analyseerde, was nog ruim twee derde van de bevolking (69 procent) voorstander van inkomensnivellering.

Naar aanleiding van het bovenstaande proberen we in deze bijdrage de volgende onderzoeksvragen voor de achterliggende decennia te beantwoorden:

1 Is de inkomensongelijkheid toegenomen, afgenomen of niet veranderd?

2 Hangen de ontwikkelingen van de inkomensongelijkheid samen met veranderingen in het opleidingsniveau, het aantal verdieners, de inkomensbron en de etnische herkomst?

3 Is de steun voor inkomensnivellering de laatste decennia afgenomen, en hoe verhoudt dit zich tot de feitelijke ontwikkeling van inkomensongelijkheid?

De eerste vraag is descriptief, en haakt aan bij de actuele discussie over de veranderende inkomensongelijkheid, met name de tegenstelling tussen degenen die haar sterk zien oplopen en zij die vooral stabiliteit waarnemen. Omdat bij economische ongelijkheid, zoals Kremer e.a. (2014: 14) in de recente WRR-bundel betogen, het gekozen criterium doorslaggevend kan zijn ('het maar is wat je vergelijkt') hanteren we in de descriptieve analyse diverse inkomensbegrippen en maatstaven: de verdeling van het primair, bruto en besteedbaar inkomen naar gedetailleerde klassen, de Ginicoëfficiënt, de Theilcoëfficiënt en de gemiddelde logdeviatie. Dat zou in beginsel ook enig zicht kunnen werpen op een alternatieve hypothese van Ganzeboom en Ultee: de mogelijke sterke inkomensgroei aan de top 
en de invloed van beleidsmaatregelen die dat tegengaan. ${ }^{4}$ De allerhoogste inkomens zijn in de hier gebruikte steekproef echter per definitie schaars vertegenwoordigd (zie ook paragraaf 2).

De tweede vraag is meer analytisch van aard. Door middel van decompositieanalyses gaan we na of het verloop van de inkomensongelijkheid samenhangt met veranderingen in het aandeel mensen in uiteenlopende categorieën; wijzigingen in het gemiddelde inkomen van die categorieën (tussengroepsongelijkheid); en veranderingen in de ongelijkheid van de inkomensverdeling binnen elke afzonderlijke categorie (de onverklaarde binnengroepsongelijkheid). We doen dit allereerst voor de verschillende opleidingsniveaus, omdat wijzigingen daarin volgens de hoofdhypothese van Ganzeboom en Ultee (1996) de sterkste drijvende kracht achter kleiner wordende inkomensverschillen zouden zijn. Op die manier brengen we in kaart of de groei van het aandeel hoger opgeleiden, en de ontwikkeling van de inkomensverschillen binnen die groep en ten opzichte van middelbaar en lager geschoolden, de financiële tegenstellingen in de loop der tijd hebben beïnvloed. Over de alternatieve opleidingshypothese die Ganzeboom en Ultee opperden - de doorwerking van koopkrachtontwikkelingen en daaraan gekoppelde veranderingen in homogamie op de inkomensongelijkheid - kunnen we met onze gegevens geen uitspraak doen. Vervolgens kijken we naar het aantal verdieners per huishouden, om de invloed van de trend naar meer tweeverdienerschap te ontrafelen die in de voorspelling van Dessens (1996) over de groeiende arbeidsdeelname van vrouwen centraal stond. Heeft dit inderdaad geleid tot een toename van de inkomensongelijkheid met 15 procent? Om dit zuiver in beeld te krijgen kijken we, anders dan Dessens, ook naar alleenstaanden en eenverdieners. Daarna bezien we de veranderingen naar inkomensbron. Dat biedt inzicht in de invloed op de inkomensongelijkheid van trendmatige ontwikkelingen als de groei van het aandeel zelfstandigen zonder personeel en de invloed van de vergrijzing en pensioenopbouw. Deze belangrijke maatschappelijke veranderingen bleven naar onze mening in de studie van Ganzeboom en Ultee (1996) in relatie tot inkomensongelijkheid ten onrechte onderbelicht. De repercussies van meer flexwerk op de inkomensontwikkelingen, één van hun alternatieve hypothesen, kunnen we via het bestand dat wij gebruiken niet nagaan, aangezien dit geen informatie over de contractvorm bevat. Tot slot voeren we een decompositie uit naar etnische herkomst. Dat doen we om zicht te krijgen op de vraag of het gestegen aandeel niet-westerse migranten in de bevolking van invloed is geweest. Heeft dit de dalende inkomensongelijkheid, die Ganzeboom en Ultee (1996) verwachtten op grond 
van de afnemende opleidingsverschillen, inderdaad getemperd, zoals één van hun alternatieve hypothesen luidde?

De derde vraag is gericht op onze vooruitberekening van de autonome trend die Hermkens (1996) indertijd onderkende. Het is van belang hierbij na te gaan in hoeverre de veranderende preferenties ten aanzien van inkomensnivellering samenhangen met de feitelijke inkomensongelijkheid. Hermkens ging daar destijds niet op in, maar de hypothese dat de voorkeur voor nivellering sterker wordt als de feitelijke inkomensverschillen toenemen wordt in de literatuur vaak genoemd. Op basis van de median voter theory heeft de doorsnee kiezer bij een grote mate van ongelijkheid in het primaire inkomen immers voordeel te verwachten van herverdeling. Die wordt in die situatie veelal bekostigd via progressieve heffingen op hogere inkomens, en dat maakt het voor een groot deel van het electoraat aantrekkelijk hun rationele preferentie voor herverdeling in het stemhokje tot uiting te brengen. Als de ongelijkheid echter al laag is, loopt de doorsnee kiezer daarentegen meer risico zelf op te moeten draaien voor verdere redistributie, en zal op grond van het eigenbelang van deze centrale groep de 'vraag naar herverdeling' lager zijn (zie verder Dallinger, 2010; Meltzer \& Richard, 1981).

\section{Data en methoden}

Bij de beantwoording van de eerste twee onderzoeksvragen moet men bedenken dat de Nederlandse inkomensgegevens sinds de studie van Ganzeboom en Ultee (1996) sterk verbeterd zijn. Zo maakte Dessens (1996) gebruik van een enquête waar respondenten zelf hun inkomen moesten opgeven. Die manier van dataverzameling leidt vaak tot onderrapportage van bepaalde inkomensbronnen, zoals vakantiegeld en incidentele beloningen. Ook is de item non-respons soms aanzienlijk: mensen geven regelmatig geen antwoord op de inkomensvragen in de enquête, omdat ze die te onthullend vinden. Ten slotte is de omvang van dergelijke steekproeven beperkt, en zijn bepaalde groepen, zoals lagere inkomens en migranten, in enquêtes vaak ondervertegenwoordigd. Zulke problemen doen zich in het bestand dat wij gebruiken niet of veel minder voor. Het Inkomenspanelonderzoek (IPO) van het CBS is gebaseerd op geanonimiseerde administratieve microgegevens van de Belastingdienst en andere instanties. De steekproef van het IPO bestond in 2012 uit circa 95.00o huishoudens met daarin 270.000 personen, die in de loop der tijd zijn gevolgd. Door de administratieve opzet is er geen sprake van (item) non-respons of ondervertegen- 
woordiging ten opzichte van de Basisregistratie Personen. Wel zijn vanzelfsprekend inkomsten die bij de overheid niet bekend zijn (bijvoorbeeld vanwege zwart werken of verzwegen buitenlandse inkomensbronnen) niet meegeteld. Het is overigens twijfelachtig of die in enquêtes wel worden gerapporteerd.

Het IPO heeft in 2000 een revisie ondergaan, waardoor de gegevens voor en na dat jaar niet geheel vergelijkbaar zijn. ${ }^{5}$ Anders dan Salverda (2013: 8994) doen wij geen poging de trendbreuk te corrigeren, en maken wij rechtstreeks gebruik van de microgegevens, niet van door het CBS opgeleverde tabellen. We kijken naar het primair, bruto en besteedbaar inkomen. ${ }^{6}$ Dit doen we voor huishoudens, omdat wanneer volwassenen samenwonen zij hun persoonlijke inkomen in de praktijk vaak samenvoegen. Het totale huishoudensinkomen is daarom de beste indicator voor de financiële positie.

Een beperking is dat het IPO geen indeling naar opleidingsniveau bevat. Om toch een decompositie naar dit kenmerk uit te kunnen voeren zijn gegevens uit de steekproef van de Enquête Beroepsbevolking (EBB, 2003-2012) gekoppeld aan de Integrale Inkomensstatistiek van het CBS. Bij de decompositie naar opleiding is de onzekerheid daardoor groter; de aantallen zijn kleiner, en voor zover de EBB selectief is in de respons en uitval zijn de gegevens ook minder betrouwbaar. Dit betreft vermoedelijk vooral een ondervertegenwoordiging van lage inkomens, lager opgeleiden en migranten.

In de beschrijvende analyses laten we eerst de veranderingen in de totale inkomensverdeling tussen 1990 en 2012 zien, op basis van gedetailleerde klassen van het primair, bruto en besteedbaar inkomen. Daarna beschrijven we de ontwikkeling van de inkomensongelijkheid op basis van drie samenvattende maten: de Ginicoëfficiënt, de Theilcoëfficiënt en de gemiddelde logdeviatie. Zij leggen binnen de inkomensverdeling verschillende accenten (Cowell \& Flachiare, 2002). De Ginicoëfficiënt is gelijk aan de helft van het gemiddelde absolute verschil tussen inkomens, gedeeld door het gemiddelde inkomen, en genormeerd op het aantal waarnemingen. Deze coëfficiënt is gevoelig voor veranderingen bij de middeninkomens, maar minder vatbaar voor wijzigingen aan de staarten van de verdeling. Ze heeft een minimum van o (totale gelijkheid) en een maximum van 1 (totale ongelijkheid). De coëfficiënt van Theil (1967) is gebaseerd op het entropieconcept uit de natuurkunde en de informatietheorie. Dat begrip verwijst naar de onzekerheid, wanorde, of gemiddelde informatieve waarde van waarnemingen. Bij de Theilcoëfficiënt neemt men per huishouden het logaritme van de verhouding tussen het waargenomen inkomen en het bevolkingsgemiddelde. Dit wordt gewogen met het aan- 
deel van het waargenomen inkomen in het totaalinkomen van de gehele bevolking, en gesommeerd. Deze maatstaf heeft eveneens een waarde van nul bij totale gelijkheid, maar het maximum is gelijk aan het logaritme van het aantal waarnemingen en in principe dus onbegrensd. Een aantrekkelijk kenmerk van de Theilcoëfficiënt is de ontleedbaarheid van ongelijkheid tussen en binnen groepen (bijvoorbeeld werknemers, zelfstandigen en uitkeringsontvangers; zie Shorrocks, 1980, 1984); bij de Ginicoëfficiënt is dat veel bewerkelijker en zijn de uitkomsten vaak lastiger te interpreteren (vergelijk Jenkins \& Van Kerm, 2009: 57). De maat van Theil heeft echter als nadeel dat het onderliggende entropiebegrip moeilijker is te doorgronden dan de Ginicoëfficiënt, die geometrisch eenvoudig uit te leggen is aan de hand van de Lorenzcurve. ${ }^{7}$ Ook is ze relatief gevoelig voor veranderingen aan de bovenkant van de inkomensverdeling: hogere inkomens hebben immers een groter aandeel in het totaalinkomen, waarmee gewogen wordt. Als onderdeel van zijn uitgebreide groep ongelijkheidsmaatstaven stelde Theil (1967) ook een variant voor die niet wordt gewogen met de inkomensaandelen: de mean log deviation (MLD), die eveneens decomponeerbaar is. Bij absolute gelijkheid is de waarde logischerwijs gelijk aan nul, de bovenkant is onbegrensd. Doordat wordt uitgegaan van het logaritme en de inkomensaandelen niet van invloed zijn is de MLD minder gevoelig voor veranderingen in hogere inkomens, en juist meer voor wijzigingen aan de onderkant.

De decompositie is gebaseerd op de benadering van Mookherjee en Shorrocks (1982). Zij legden voor de periode 1965-1980 de veranderingen in de gemiddelde logdeviatie voor het Verenigd Koninkrijk uiteen in de invloed van mutaties in de bevolkingsaandelen van groepen, hun gemiddelde inkomen en de inkomensongelijkheid binnen de groepen. Wij volgen de uitwerking daarvan zoals toegepast door Pommer e.a. (2003: 75-79, 265293); eerder gebruikten we eenzelfde methode om de historische veranderingen in de armoedeprevalentie te analyseren (Vrooman \& Wildeboer Schut, 2013).

De derde onderzoeksvraag kunnen we rechtstreeks beantwoorden. Voor de analyse van de veranderende inkomenspreferenties van de bevolking gebruiken we evenals Hermkens (1996) de gegevens uit Culturele Veranderingen in Nederland, maar de beschikbare tijdreeks loopt inmiddels tot en met 2012. Anders dan Hermkens kijken wij naar de gemiddelde scores op de oorspronkelijke vijfpuntsschaal, niet naar het percentage mensen dat vindt dat de inkomensverschillen (veel) kleiner moeten worden. Dit heeft als voordeel dat alle antwoordcategorieën in de indicator meetellen. 


\section{Uitkomsten}

In deze paragraaf gaan we eerst in op de vorm van de inkomensverdeling in 1990 en 2012, en op de uitwerking van de trendbreuk in 2000/2001. Vervolgens bespreken we een aantal samenvattende maatstaven, waarbij we ook kijken naar de tussenliggende jaren. Daarna proberen we de verandering in twee van die maatstaven, de gemiddelde logdeviatie en de Theilcoëfficiënt, via decomposities te interpreteren. Ten slotte bespreken we de ontwikkeling van de opvattingen over inkomensnivellering onder de bevolking, en de relatie daarvan met feitelijke veranderingen in inkomensongelijkheid.

\subsection{Veranderende verdelingen}

Figuur 1 biedt een gedetailleerd overzicht van de verdeling van het primair, bruto en besteedbaar jaarinkomen bij Nederlandse huishoudens in 1990 (ononderbroken lijn) en 2012 (histogram). Om zicht te krijgen op de invloed van de trendbreuk in het IPO zijn bovendien de niveaus in de jaren 2000 en 2001 weergegeven (lichtgekleurde en donkere peilstreepjes). De huishoudens zijn ingedeeld in klassen van duizend euro in het prijspeil van 2012, maar vanwege kleinere aantallen is het onderscheid bij negatieve inkomens en vanaf $€ 110.000$ minder fijnmazig. In alle jaren is het opgehoogde totaalaantal door herweging genormaliseerd naar de 7,4 miljoen IPO-huishoudens van 2012. Zodoende zijn de verdelingen van de vier jaren visueel rechtstreeks vergelijkbaar.

Als men de verdeling van het primair inkomen in 1990 en 2012 vergelijkt zijn de veranderingen op het eerste gezicht spectaculair. De loon-, winst- en vermogensinkomens vertoonden op het eerste meetpunt twee duidelijke pieken: de zeer grote groep AOW'ers en uitkeringsontvangers die zulke inkomsten niet of nauwelijks had, en de middengroep met een inkomen rond $€$ 37.00o. Twee decennia later is de piek bij de middeninkomens afgevlakt en op een iets hoger niveau beland (circa $€ 42.000$ ), terwijl de groep met een bovenmodaal of hoog inkomen (vanaf $€ 56.000$ ) veel omvangrijker werd. Helemaal aan de bovenkant springt de toename het meest in het oog, al komt dat ook door de grove klassenindeling. Deze ontwikkeling zou op toenemende ongelijkheid duiden. Het grote aantal nulinkomens werd van 1990 op 2012 echter veel kleiner, en dat wordt niet gecompenseerd door de groei van de inkomens tot duizend euro; per saldo drukt dit de ongelijkheidstoename.

Bij nadere beschouwing blijken de veranderingen in de ongelijkheid tussen het eerste en het laatste meetpunt echter voor een behoorlijk deel een artefact van de trendbreuk in de gegevens te zijn. De verdeling van 2000 lijkt in de figuur immers nogal op die van 199o, terwijl die van 2012 vrij dicht 
bij die van 2001 ligt. Het grootste deel van de veranderingen in de verdeling doet zich dus voor met de gegevenstrendbreuk van 2000 op 2001. Dit houdt in dat we de ontwikkeling van de inkomensongelijkheid beter kunnen analyseren voor twee afzonderlijke tijdvakken, voor en na de trendbreuk.

Van 1990 op 2000 daalde het aantal nulinkomens met 270.000; dit kan een gevolg zijn van de oplopende werkgelegenheid en de inperkingen van de WW, de WAO, de Nabestaandenwet en de bijstandsregeling, waardoor het beroep op de sociale zekerheid verminderde (Vrooman, 2012a). Ook zeer kleine positieve inkomens, tot maximaal $€$ 2.00o per jaar, kwamen aan het begin van het millennium minder vaak voor dan tien jaar eerder (-95.000). Daar staat tegenover dat het aantal negatieve inkomens toenam, en er ook meer lagere inkomens zijn; de piek bij de middeninkomens is in 2000 iets afgevlakt en ligt op een lager niveau ( $€$ 34.00o) dan in 1990. Mogelijk hangt dit samen met de toenemende deeltijdarbeid bij vrouwen (waardoor er op huishoudensniveau altijd nog een bedrag resteert als het inkomen van de partner wegvalt) en groeiende bijverdiensten onder studenten. In de hogere inkomensklassen vallen de verdelingen in 1990 en 2000 vrijwel samen. Voor zover er van 1990 op 2000 veranderingen waren, deden die zich dus vooral voor aan de onderkant van de primaire inkomensverdeling. Ze zijn echter niet eenduidig, waardoor op basis van de grafiek niet geconcludeerd kan worden dat de totale ongelijkheid tussen deze meetpunten sterk veranderde.

Van 2001 op 2012 nam de ongelijkheid van de primaire inkomens echter wel toe. Het aantal negatieve inkomens steeg vrij sterk $(+132.000)$, al groeide de groep die meer dan $€ 30.000$ in het rood verkeerde niet. De toename zat vooral in de kleine negatieve inkomens, tot $-€ 5$.00o. Door de trendbreuk in de gegevens verminderde het aantal nulinkomens met 1 miljoen, terwijl de groep met een klein positief inkomen (minder dan duizend euro) met 640.000 huishoudens groeide. Dit weerspiegelt de betere waarneming van vermogensinkomsten. Van 2001 op 2012 veranderde dit nauwelijks. Bij de positieve inkomens zien we enige polarisatie: tot $€ 25.000$ en boven $€ 87.000$ was meestal sprake van een toename, maar de inkomens daartussenin kwamen minder vaak voor. De groep met een primair huishoudensinkomen van meer dan $€ 100.000$ werd van 2001 op 2012 bijna een derde groter, en omvatte op het laatste meetpunt één op de negen huishoudens. ${ }^{8}$

In de berekening van het bruto jaarinkomen zijn uitkeringen als AOW, WW, WAO en bijstand, de aanvullende pensioenen en diverse toeslagen verdisconteerd. Dat houdt logischerwijs in dat het aantal nulinkomens verwaarloosbaar is. In 1990 zien we nu, naast de piek bij de middeninkomens, een aantal toppen rond de sociale minima voor uiteenlopende typen huishoudens. 


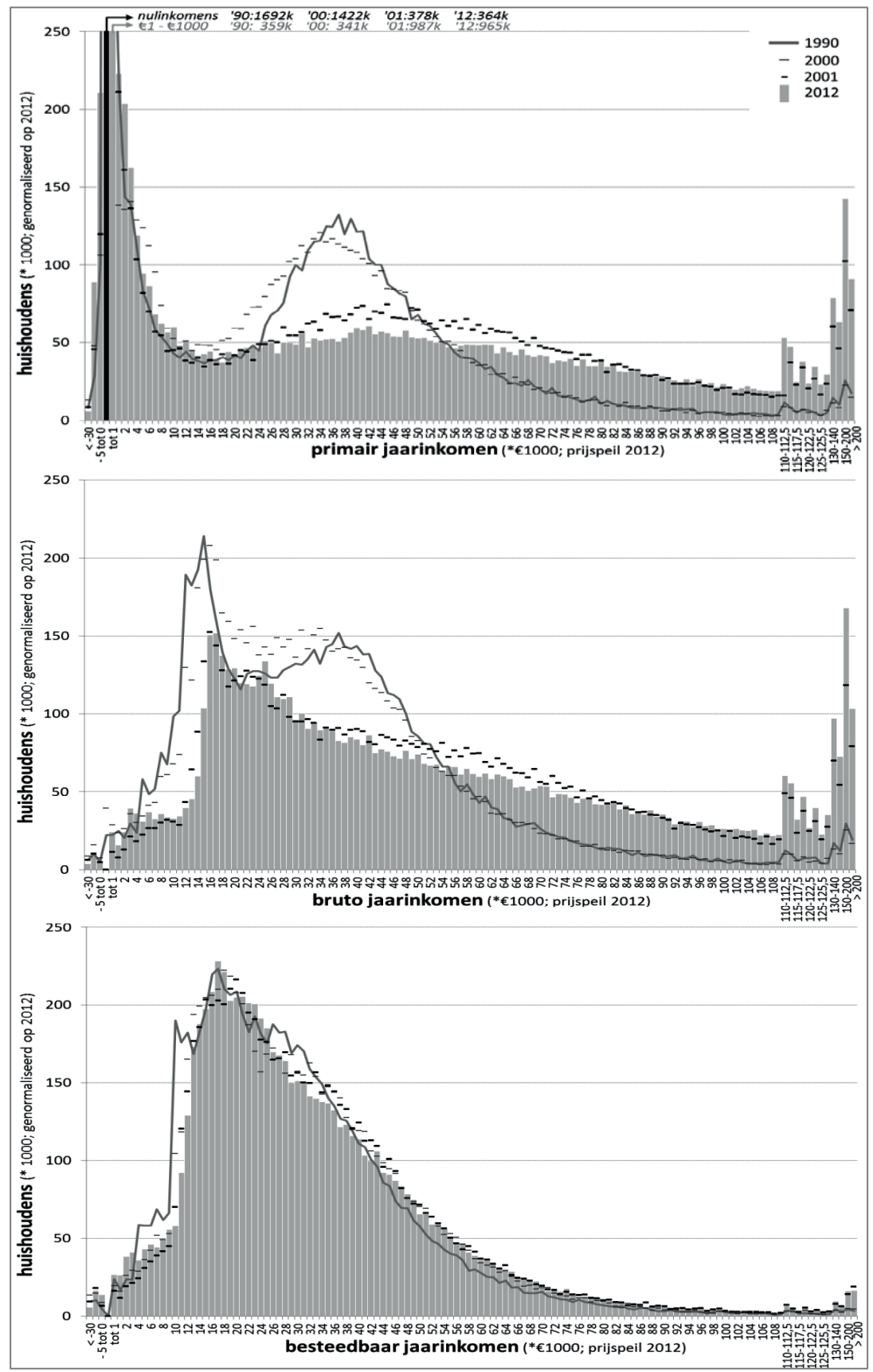

Figuur 1 Inkomensverdelingen in 1990, 2000, 2001 en 2012

Bron: Inkomenspanelonderzoek 1990-2012 (CBS; bewerking) 
Bij de hogere inkomensgroepen, vanaf $€ 56$.0oo, is van 1990 op 2000 nauwelijks iets veranderd, zoals we ook al bij de primaire inkomens zagen. Daaronder is sprake van een gemengd beeld. De bruto inkomens tot $€ 4.000$ (met inbegrip van de negatieve inkomens) groeiden in aantal, terwijl de lage inkomens daarboven, tot $€ \mathbf{1 5 . 0 0 0}$, wat minder vaak voorkwamen. De groep van $€$ 16-35.00o werd omvangrijker, de categorie van $€$ 36-56.0oo kleiner. Van 2001 op 2012 zijn de veranderingen in het bruto inkomen beperkt: de vorm van de verdelingen vertoont in figuur 1 in beide jaren grote gelijkenis en is nu ééntoppig (de pieken bij de hogere inkomens komen voort uit de grovere klassenindeling). Het aantal negatieve inkomens is stabiel, terwijl zeer lage inkomens in 2012 wat vaker voorkomen. De groep van $€$ 11-17.000 is dat jaar minder talrijk geworden. Tot $€ 37.000$ gaan beide verdelingen bijna gelijk op, terwijl de groep daarboven, van $€$ 37-89.00o, in 2012 kleiner is. Evenals bij de primaire inkomens werden de hoogste groepen talrijker. Dit alles duidt per saldo op licht oplopende ongelijkheid door enige polarisatie, maar die is minder geprononceerd dan bij de primaire inkomens.

De verdelingen naar besteedbaar jaarinkomen liggen vrij dicht op elkaar, en hebben in alle gevallen een lognormale vorm. Van 1990 op 2000 nemen de lage inkomens ( $€$ 4-33.00o) iets in aantal af, terwijl de (hogere) middeninkomens tot $€ 82$.00o talrijker worden. Omdat de groep daarboven vrijwel constant in omvang is, duidt dit op een licht afnemende ongelijkheid aan de onderkant.

Van 2001 op 2012 zijn de verdelingen vrijwel identiek. Er is sprake van een lichte toename in de categorieën tot $€ 10.000$ (ook bij de kleine negatieve inkomens) en meestal ook in de groep tussen $€$ 15-27.0oo. Daar staan bescheiden afnames tegenover in de groepen van $€$ 10-13.000 en $€$ 2846.ooo. Daarboven is het beeld van 2001 op 2012 stabiel. Het is ook tamelijk uitzonderlijk wanneer huishoudens een besteedbaar inkomen hebben dat $€ 100.000$ te boven gaat. Dat waren er in 2012 111.00o, wat overeenkomt met 1,5 procent van alle huishoudens - een veel kleinere groep dan we eerder bij de verdelingen van primair en besteedbaar inkomen zagen. De groep met een besteedbaar huishoudensinkomen van $€ 200.000$ of meer is nog zeldzamer: in 2012 bestond ze uit circa 16.000 huishoudens (0,2 procent). Het overheersende beeld is dat de ongelijkheid in besteedbaar inkomen van 2001 op 2012 licht toenam; maar niet door een sterke groei van de hoge inkomens, maar vanwege een verschuiving van lage-middeninkomens naar lage inkomens. Dit duidt eerder op een toenemend armoedeprobleem dan op scherpere contrasten tussen de top en de onderkant (SCP/CBS, 2014). 


\subsection{Inkomensongelijkheid van jaar tot jaar}

Tussen de vier besproken meetpunten in kan nog van alles veranderd zijn. Figuur 2 brengt daarom de wijzigingen van jaar tot jaar in beeld, aan de hand van enkele gebruikelijke ongelijkheidsmaten die verschillende accenten leggen (zie paragraaf 2). De waarden op de Gini-coëfficiënt, de Theilcoëfficiënt en de gemiddelde logdeviatie zijn met 100 vermenigvuldigd. Omdat de maatstaven niet goed overweg kunnen met negatieve en nulinkomens is het onderste percentiel van de besteedbare inkomens in alle jaren buiten beschouwing gelaten. Voor het primair inkomen is dat bij de gemiddelde logdeviatie niet afdoende; die maat is daarom niet in de grafiek opgenomen. ${ }^{9}$

In de jaren negentig neemt de ongelijkheid in primaire inkomens op basis van de Gini- en Theilcoëfficiënt aanvankelijk toe, maar in de periode 1995-1999 treedt een daling op die scherper is. Daardoor zijn de verschillen in 2000 uiteindelijk twee à drie punten kleiner dan tien jaar eerder. Dat is een duidelijker conclusie dan uit figuur 1 naar voren kwam. De afname van de negatieve en nulinkomens is bij de berekening van de maatstaven niet verdisconteerd, waardoor het accent komt te liggen bij de eerder gesignaleerde toename van het aantal lage positieve inkomens en de afname van de middengroep. Tijdens het nieuwe millennium lopen de verschillen in de primaire inkomens volgens beide maatstaven licht op, met een piek in 2007. Dit laatste houdt verband met een belastingmaatregel waarvan hogere inkomens dat jaar eenmalig profijt hadden; het effect is bij de Theilcoëfficiënt dan ook groter dan bij de Gini. ${ }^{10}$ Bij aanvang van de recessie daalt de inkomensongelijkheid eerst, maar na 2008 neemt ze weer toe. Uiteindelijk is de ongelijkheid in het primaire inkomen tussen 2001 en 2012 met vier punten gestegen volgens de Ginimaatstaf, en met zes punten volgens de Theilcoëfficiënt. Uit figuur 1 bleek dit vooral een kwestie van polarisatie: er waren in 2012 meer huishoudens met een laag èn met een hoog primair inkomen dan in 2001, terwijl de middengroep slonk. Per saldo is de daling in de jaren negentig in het nieuwe millennium tenietgedaan, en resteert - voorbijgaand aan de trendbreuk - over de gehele periode bezien een kleine toename van twee à drie punten. 


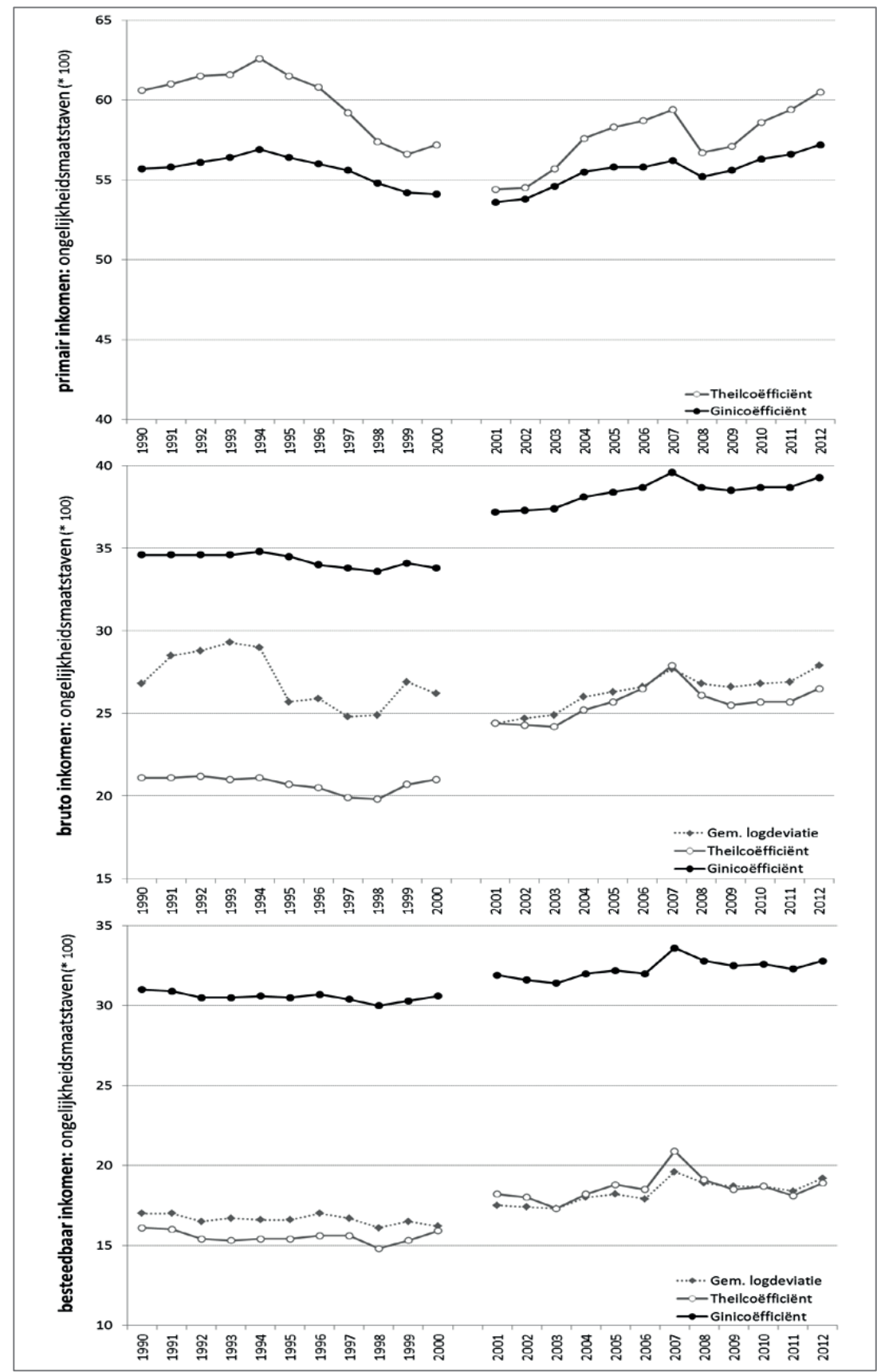

Figuur 2 Veranderingen in inkomensongelijkheid volgens drie ongelijkheidsmaatstaven, 1990-2012 ${ }^{a}$

a 2000: trendbreuk in de gegevens.

Bron: Inkomenspanelonderzoek 1990-2012 (CBS; bewerking) 
Wanneer de uitkeringen en de pensioenen worden meegerekend zijn de ongelijkheidsniveaus lager en is de ontwikkeling gelijkmatiger. In de jaren negentig van de vorige eeuw was de ongelijkheid in de bruto inkomens aanvankelijk vrijwel stabiel, om in de tweede helft iets te dalen en aan het eind weer wat op te lopen. Bij de MLD is het verloop wat springerig, hetgeen samenhangt met jaarverschillen in de resterende negatieve en nulinkomens. ${ }^{11}$ Afgezet tegen 1990 was de bruto-inkomensongelijkheid in 2000 volgens de Theilcoëfficiënt nauwelijks teruggelopen, en bedroeg de afname op basis van de beide andere maten één punt. Dit weerspiegelt dat er aan de bovenkant van de inkomensverdeling weinig veranderde, terwijl aan de onderkant sprake was van complexere wijzigingen (zie figuur 1). $\mathrm{Na}$ 2000 zien we ook bij de bruto inkomens de ongelijkheid tot 2007 licht oplopen, al is dat minder geprononceerd dan bij de primaire. Daarna is volgens alle maatstaven gedurende twee jaar sprake van een afname, en in 2012 weer van een toename. In het laatste meetjaar waren de Gini- en de Theilcoëfficiënt van het bruto inkomen twee punten hoger dan in 2001; volgens de MLD bedroeg dit vier punten. De licht stijgende ongelijkheid sinds 2001 overtreft dus de bescheiden daling in de jaren negentig. Afgezien van de trendbreuk was de totale stijging sinds 1990 één tot drie punten, en minder groot dan bij de primaire inkomens.

Als we ook de betaalde belastingen en premies toevoegen daalt het niveau van de ongelijkheid verder, en wordt de volatiliteit minder. De ongelijkheid van het besteedbaar inkomen is in de jaren negentig volgens alle maatstaven tamelijk stabiel: een kleine afname aan het begin van het decennium en in 1997-1998, gevolgd door een beperkte toename rond de eeuwwisseling. Per saldo daalden de drie coëfficiënten tussen 1990 en 2000 licht, met 0,2 tot 0,8 punt. In het nieuwe millennium daalt de ongelijkheid van het besteedbaar inkomen eerst verder, om na 2003 op te lopen tot de piek in 2007 - mede het gevolg van de al gememoreerde belastingmaatregel. Daarna daalt de inkomensongelijkheid volgens alle maatstaven iets, om vervolgens te stabiliseren en in 2012 weer iets toe te nemen. Uiteindelijk ligt de ongelijkheid in 2012 volgens de Theilcoëfficiënt 0,7 punt hoger dan in 2001, en op basis van de Ginicoëfficiënt 0,9 punt. Bij de gemiddelde logdeviatie was de toename met 1,7 punt vrij groot. Dit onderstreept dat ontwikkelingen aan de onderkant de ongelijkheid in het besteedbaar inkomen in deze periode iets hebben doen oplopen (zie figuur 1): er is eerder sprake van een groter wordend armoedeprobleem, dan van een breder wordende kloof tussen de hoge inkomens en de rest. ${ }^{12}$ Als we abstraheren van de trendbreuk in de gegevens is de ongelijkheid in het besteedbaar 
inkomen vanaf 1990 bezien licht opgelopen, met 0,5 punt (Theil en Gini) tot 0,9 punt (MLD).

\subsection{De veranderingen uiteengelegd}

Wanneer we voorbijgaan aan de invloed van de trendbreuk in de gegevens is de inkomensongelijkheid sinds 1990 op basis van de verdelingen en de maatstaven slechts licht veranderd. De wijzigingen die we constateerden gaan bovendien niet de kant op die Ganzeboom en Ultee (1996) destijds voorspelden. In de jaren negentig zien we soms een kleine afname, maar de trend in het nieuwe millennium is licht stijgend. Dat laatste is het meest uitgesproken bij het primaire inkomen, en het minst bij het besteedbaar inkomen. Dit roept de vraag op of de hoofdhypothese van Ganzeboom en Ultee voor de hier onderzochte periode als verworpen moet worden beschouwd. Dat wil zeggen: veranderingen in het opleidingsniveau hebben de inkomensongelijkheid niet merkbaar beïnvloed, of ze zijn gekeerd door andere ontwikkelingen, zoals de groeiende arbeidsdeelname van vrouwen, de instroom van kansarme migranten, de toename van zelfstandigen en de ontwikkelingen in de uitkeringen en pensioenen. De uitkomsten van de decompositie-analyse in tabel 1 werpen hier licht op. Dat gebeurt uitsluitend voor de Theilcoëfficiënt en de MLD, omdat een decompositie van de Ginicoëfficiënt te bewerkelijk is. Ook beperken we ons tot de ongelijkheid in de besteedbare inkomens: de bedragen die mensen daadwerkelijk ontvingen en die het meest indicatief zijn voor hun economische positie en de daaraan gekoppelde levenskansen. In de decompositie gaan we, anders dan in figuur 2, uit van procentuele veranderingen in de ongelijkheidsmaatstaven.

\subsubsection{Opleidingsniveau}

Als gezegd is de decompositie naar opleidingsniveau beperkt omdat dit kenmerk in het Inkomenspanelonderzoek ontbreekt. De met inkomen verrijkte EBB-gegevens vanaf 2003 die we hier als alternatieve bron gebruiken leveren iets andere uitkomsten op. Terwijl de Theilcoëfficiënt volgens het IPO tussen 2003 en 2012 met negen procent toenam, en de gemiddelde logdeviatie met elf procent, is de verandering volgens de verrijkte EBBdata respectievelijk -o,6 procent en +3 procent. Dat noopt, vanwege de geringere kwaliteit van de laatstgenoemde gegevens, tot voorzichtigheid bij de interpretatie. Vermeldenswaard is wel dat Pommer e.a. (2003) een vergelijkbare decompositie naar opleidingsniveau verrichtten op basis van de gegevens van het AVO. Voor de periode 1990-1998 bleken veranderingen in het opleidingsniveau nauwelijks van invloed op de ontwikkeling van de 
ongelijkheid in het (gestandaardiseerde) besteedbaar huishoudensinkomen. Datzelfde zien we voor 2003-2012 in tabel 1: door de gewijzigde opleidingsverdeling neemt de ongelijkheid volgens beide maten met één procent toe, terwijl de ontwikkeling van de gemiddelde inkomens binnen opleidingscategorieën nauwelijks doorwerkte (het effect is licht negatief, maar na afronding nihil). De verschillen tussen de Theilcoëfficiënt en de MLD ontstaan door het onverklaarde deel: de binnengroepsongelijkheid daalt volgens de Theilcoëfficient iets, maar loopt bij de gemiddelde logdeviatie licht op. Tabel Ar (zie appendix) toont de onderliggende ontwikkelingen. Tussen 2003 en 2012 nam het aandeel hoger opgeleiden toe, terwijl de groep met lager en middelbaar onderwijs kleiner werd. Na correctie voor de prijsinflatie daalde het gemiddelde inkomen van de meeste opleidingsgroepen; dit was het meest uitgesproken bij de hoger opgeleiden (circa $€ 2.000$ op jaarbasis). Binnen de opleidingsgroepen daalde de inkomensongelijkheid op basis van de Theilcoëfficiënt bij de lager opgeleiden (maximaal vmbo/mavo), terwijl ze voor het overige stabiel was; het is dus logisch dat dit per saldo resulteert in een kleinere totale binnengroepsongelijkheid. Volgens de MLD nam die uitsluitend, en dan nog zeer licht, af bij de groep met ten hoogste basisonderwijs. Bij hbo'ers en academici liep ze in wat sterkere mate op, waardoor er over alle groepen bezien sprake is van een toename. Deze uitkomsten duiden er in combinatie met die van Pommer e.a. (2003) niet op dat veranderingen naar opleiding de verschillen in het besteedbaar inkomen substantieel hebben doen afnemen, zoals Ganzeboom en Ultee (1996) op grond van de moderniseringstheorie verwachtten. Mogelijk heeft de onderwijsexpansie de inkomensongelijkheid in het nieuwe millennium iets doen oplopen vanwege het gestegen human capital onder de bevolking, en is dat bescheiden effect licht getemperd doordat hoger opgeleiden minder schaars werden en hun beloning verhoudingsgewijs achterbleef. Het grootste deel van de veranderende ongelijkheid in het besteedbaar inkomen lijkt echter niet vanuit opleidingsontwikkelingen te kunnen worden verklaard. 
Tabel 1 Decompositie van veranderingen in de ongelijkheid van het besteedbaar inkomen, 1990-2000 en 2001-2012

\begin{tabular}{|c|c|c|c|c|c|c|c|c|}
\hline \multirow[b]{2}{*}{ Variabele } & \multicolumn{4}{|c|}{$1990-2000(\%)$} & \multicolumn{4}{|c|}{$2001-2012^{\mathrm{a}}(\%)$} \\
\hline & $\begin{array}{r}\Delta \text { aan- } \\
\text { deel }\end{array}$ & $\begin{array}{l}\text { gem. } \\
\text { ink. }\end{array}$ & $\begin{array}{r}\Delta \text { bin- } \\
\text { nen }\end{array}$ & $\begin{array}{r}\Delta \text { to- } \\
\text { taal }\end{array}$ & $\begin{array}{r}\Delta \text { aan- } \\
\text { deel }\end{array}$ & $\begin{array}{r}\text { gem. } \\
\text { ink. }\end{array}$ & $\begin{array}{r}\Delta \text { bin- } \\
\text { nen }\end{array}$ & $\begin{array}{r}\Delta \text { to- } \\
\text { taal }\end{array}$ \\
\hline \multicolumn{9}{|l|}{ Opleidingsniveau $^{\mathrm{a}}$} \\
\hline Theilcoëfficiënt & - & - & - & - & 1 & 0 & -1 & -1 \\
\hline Gemiddelde logdeviatie & - & - & - & - & 1 & 0 & 2 & 3 \\
\hline \multicolumn{9}{|l|}{ Aantal verdieners } \\
\hline Theilcoëfficiënt & -2 & 2 & -2 & -2 & 1 & 5 & -2 & 4 \\
\hline Gemiddelde logdeviatie & 6 & -6 & -4 & -4 & 3 & 4 & 3 & 10 \\
\hline \multicolumn{9}{|l|}{ Belangrijkste inkomensbron hh. } \\
\hline Theilcoëfficiënt & -1 & -6 & 5 & -2 & 6 & -3 & 0 & 4 \\
\hline Gemiddelde logdeviatie & -2 & -5 & 2 & -4 & 7 & -1 & 4 & 10 \\
\hline \multicolumn{9}{|l|}{ Etnische herkomst } \\
\hline Theilcoëfficiënt & 1 & 0 & -3 & -2 & 1 & 0 & 3 & 4 \\
\hline Gemiddelde logdeviatie & 1 & 0 & -5 & -4 & 0 & 1 & 9 & 10 \\
\hline \multicolumn{9}{|c|}{$\begin{array}{l}\text { a Opleidingsniveau: } 2003-2012 \\
\Delta \text { aandeel: procentuele verandering ongelijkheidsmaatstaf door wijziging van groepsaandelen } \\
\Delta \text { gem. ink.: procentuele verandering ongelijkheidsmaatstaf door wijziging van gemiddelde groepsinkomens } \\
\Delta \text { binnen: procentuele verandering ongelijkheidsmaatstaf door wijziging van binnengroepsongelijkheid } \\
\Delta \text { totaal: procentuele verandering ongelijkheidsmaatstaf } \\
\text { Bron: Inkomenspanelonderzoek 1990-2012; Enquête beroepsbevolking gekoppeld aan Integrale Inkomensstatis- } \\
\text { tiek, 2003-2012 (CBS; bewerking) }\end{array}$} \\
\hline
\end{tabular}

\subsubsection{Aantal verdieners}

In de hier verrichte analyse maken we een onderscheid tussen alleenstaanden (de categorie 'overig' is hier aan toegevoegd), paren met één verdiener, en tweeverdieners. ${ }^{13}$ Aan tabel A $\mathrm{in}$ de appendix lezen we af dat de groep mensen die in een eenverdienerhuishouden verbleef tussen 1990 en 2012 sterk in omvang afnam, van 31 naar 6 procent. Een derde van die daling houdt verband met de trendbreuk in het IPO. Verder is huishoudensverdunning en diversificatie opgetreden (er kwamen meer alleenstaanden, eenoudergezinnen en meerpersoonshuishoudens), waardoor de totale groep paren slonk. Binnen de laatste groep werd tweeverdienerschap de norm: het aandeel van die bevolkingsgroep groeide gestaag. Ze omvat niet uitsluitend werkenden, maar bijvoorbeeld ook paren die elk afzonderlijk AOW ontvangen. Het gemiddeld inkomen van tweeverdieners stijgt vooral in de jaren negentig sterk $(+€ 3.000$ per jaar), daarna vlakt dit af. De geslonken groep eenverdieners maakt in beide perioden een inkomensdaling door, terwijl de alleenstaanden en overigen tussen 2001 en 2012 ongeveer kwijtraakten wat ze in het decennium ervoor gemiddeld aan inkomen 
hadden gewonnen. De binnengroepsongelijkheid daalt in de jaren negentig licht bij alleenstaanden en (volgens de Theilcoëfficiënt) tweeverdieners; in het nieuwe millennium neemt ze bij de groep alleenstaanden/overig op basis van de Theilcoëfficiënt iets af en aan de hand van de MLD iets toe. In alle jaren is de binnengroepsongelijkheid bij de tweeverdieners het kleinst.

Uit de decompositie blijkt dat in de jaren negentig de effecten van de veranderende groepsaandelen en de gemiddelde inkomens elkaar opheffen. ${ }^{14}$ Dat houdt in dat de afnemende inkomensongelijkheid tussen 1990 en 2000 gelijk is aan het resultaat van de onverklaarde component (veranderingen in de binnengroepsongelijkheid). Van 2001 op 2012 hebben de wijzigingen in de aandelen en in het gemiddeld inkomen van de groepen de inkomensongelijkheid met zes á zeven procent opgestuwd. De groep eenverdieners slinkt verder en valt nog meer in inkomen terug, de groei in het aandeel tweeverdieners en van hun gemiddeld inkomen zet door maar is meer gematigd, en de categorie alleenstaanden/overig neemt meer in omvang toe maar ziet het inkomen teruglopen. De verandering in de (onverklaarde) binnengroepsongelijkheid heeft de ongelijkheid volgens de Theilcoëfficiënt teruggedrongen, en volgens de gemiddelde logdeviatie versterkt. Per saldo is van de veronderstelling van Dessens dat de groei van het tweeverdienerschap de ongelijkheid met 15 procent op zou stuwen iets minder dan de helft gerealiseerd. Dit gebeurde echter uitsluitend na de eeuwwisseling, en is met inbegrip van de invloed van de veranderingen bij alleenstaanden en eenverdieners op de inkomensverdeling.

\subsubsection{Voornaamste inkomensbron}

In de analyses geldt de inkomensbron die voor het huishouden het meeste inkomen genereert als de voornaamste. Uit tabel Aı in de appendix blijkt dat het aandeel van de pensioenontvangers in de bevolking vooral vanaf 2001 groeide, en dat hun gemiddeld inkomen gestaag toenam. Dit weerspiegelt de vergrijzing en de verbetering van de aanvullende pensioenen bij de jongere cohorten. Het aandeel zelfstandigen (met en zonder personeel dit valt in het IPO niet te onderscheiden) nam in beide perioden toe, met de sterkste stijging na 2001. Het gemiddeld besteedbaar jaarinkomen van de groep daalde zowel in de jaren negentig als na de eeuwwisseling, met ongeveer $€$ 3.00o. De binnengroepsongelijkheid is bij de zelfstandigen hoog en vrij stabiel, maar van 2001 op 2012 daalde ze bij de Theilcoëfficiënt wel en bij de gemiddelde logdeviatie niet; dit duidt op afnemende verschillen aan de bovenkant van de verdeling van de winstinkomens. Het aandeel van mensen in loondienst nam in de periode 1990-2000 toe, terwijl ook hun gemiddeld inkomen steeg. Naast conjunctuurschommelingen komt hierin 
ook de bijdrage van de groeiende groep werkende vrouwen aan het huishoudensinkomen tot uiting, en het langer doorwerken van ouderen. Na de eeuwwisseling kwamen er verhoudingsgewijs minder loontrekkenden, bij een gelijkblijvend gemiddeld inkomen. Dit reflecteert de ongunstige werkgelegenheidsontwikkeling tijdens de recessie sinds 2008, en de overgang van een deel van deze groep naar de categorie zelfstandigen zonder personeel (zie Josten e.a., 2014). De groepsaandelen van de uitkeringsontvangers beneden de pensioenleeftijd namen in de loop der tijd af, vooral bij de vroeggepensioneerden. Het gemiddeld inkomen daalde met name onder arbeidsongeschikten. De kleine groep 'overigen', waaronder bijvoorbeeld studenten, lijkt voor en na de trendbreuk in de gegevens anders samengesteld. Dat blijkt onder andere uit het grote verschil in het gemiddelde inkomen: in het jaar van de trendbreuk halveert dit. In de jaren negentig stijgt het gemiddeld inkomen van de restcategorie, terwijl de inkomensongelijkheid binnen de tamelijk kleine groep sterk afnam. Na de eeuwwisseling groeit het aandeel van de categorie 'overig', daalt hun gemiddeld inkomen, en neemt de binnengroepsongelijkheid af.

De decompositie in tabel 1 wijst uit dat de inkomensbron in beide tijdvakken vrij bepalend is voor de veranderingen in de inkomensongelijkheid. In de jaren negentig zijn vooral de veranderingen in de gemiddelde inkomens verantwoordelijk voor de afnemende ongelijkheid, terwijl na de eeuwwisseling de wijzigingen in de groepsaandelen bepalend zijn voor de oplopende inkomensverschillen. Tabel A1 maakt duidelijk dat de lichte daling in de ongelijkheid van het besteedbaar inkomen tussen 1990 en 2000 vooral voortkomt uit lagere winstinkomens, en stijgende pensioenen en overige inkomensbronnen. Van 2001 op 2010 houdt de - iets sterkere stijging van de inkomensongelijkheid vooral verband met minder loontrekkenden, en meer zelfstandigen en gepensioneerden (plus zes à zeven procent). Bij de beide laatste groepen zet de daling, respectievelijk stijging, van het gemiddelde inkomen zich in het nieuwe millennium voort. De lagere winsten en hogere pensioenen temperen de ongelijkheidstoename iets (minus één à drie procent). De toename van de pensioenhoogtes is het gevolg van cohorteffecten (meer en betere pensioenen bij de mensen die met werken stoppen) en belastingmaatregelen (ouderenaftrek). Op groepsniveau overtreffen die de invloed van de kortingen op de aanvullende pensioenen die enkele fondsen in 2012 doorvoerden.

\subsubsection{Etnische herkomst}

Bij de indeling naar etnische herkomst volgen we de gebruikelijke CBSmethode op basis van het geboorteland van de ouders. De belangrijkste 
ontwikkeling is de sterke toename van het aandeel niet-westerse allochtonen: van vier procent in 1990 tot tien procent in 2012 (zie tabel A1 in de appendix). De relatieve omvang van de autochtone groep daalt navenant, al is die met 80 procent in het laatste meetjaar nog veruit in de meerderheid. Hun getalsmatige overwicht houdt logischerwijs in dat veranderingen in de totale inkomensongelijkheid al snel af zullen hangen van wat er bij de autochtone groep gebeurt. De gemiddelde inkomens van niet-westerse allochtonen zijn op alle meetpunten ongeveer een derde lager dan bij de westerse allochtonen en autochtonen (-€ 8.000 à $€ 10.000$ op jaarbasis). De spreiding daaromheen loopt in de drie etnische groepen echter niet sterk uiteen: de binnengroepsongelijkheid varieert niet veel. Wel daalt ze bij niet-westerse allochtonen van 1990 op 2000 wat meer dan bij autochtonen, en neemt ze van 2001 op 2012 juist iets meer toe.

Gezien het bovenstaande is het niet verrassend dat deze factor nauwelijks van invloed is op de ontwikkeling van de inkomensongelijkheid: de onverklaarde binnengroepsongelijkheid is volgens de decompositie in tabel 1 in beide tijdvakken de belangrijkste factor. Het groeiend aandeel niet-westers allochtonen verhoogt de inkomensongelijkheid in de decennia voor en na de eeuwwisseling met maximaal één procent.

\subsection{Minder steun voor nivellering?}

Als we ten slotte kijken naar de ontwikkeling van het oordeel dat de bevolking over inkomensherverdeling heeft, dan blijkt de autonoom dalende trend (minder steun voor nivellering) die Hermkens (1996) waarnam de afgelopen decennia niet te hebben doorgezet. Figuur 3 toont de gemiddelde scores op de enquêtevraag 'Moeten de verschillen in inkomen veel groter worden, een beetje groter worden, hetzelfde blijven, een beetje kleiner worden of veel kleiner worden?', uit het langlopende project Culturele Veranderingen in Nederland van het SCP. In de periode 1980-1994 zien ook wij een dalende trend in de steun voor nivellering. Achteraf bleek 1991 echter een keerpunt, dat Hermkens destijds in zijn kortere tijdreeks nog niet kon waarnemen. Sinds dat jaar is de steun voor nivellering veelal toegenomen, met een hoogtepunt in 2008 , toen de score ongeveer weer op het peil van 1975 was beland en beduidend boven het peil van het midden van de jaren negentig lag. ${ }^{15}$ Hermkens' impliciete verwachting dat de autonome trend zou aanhouden is dus niet uitgekomen. 


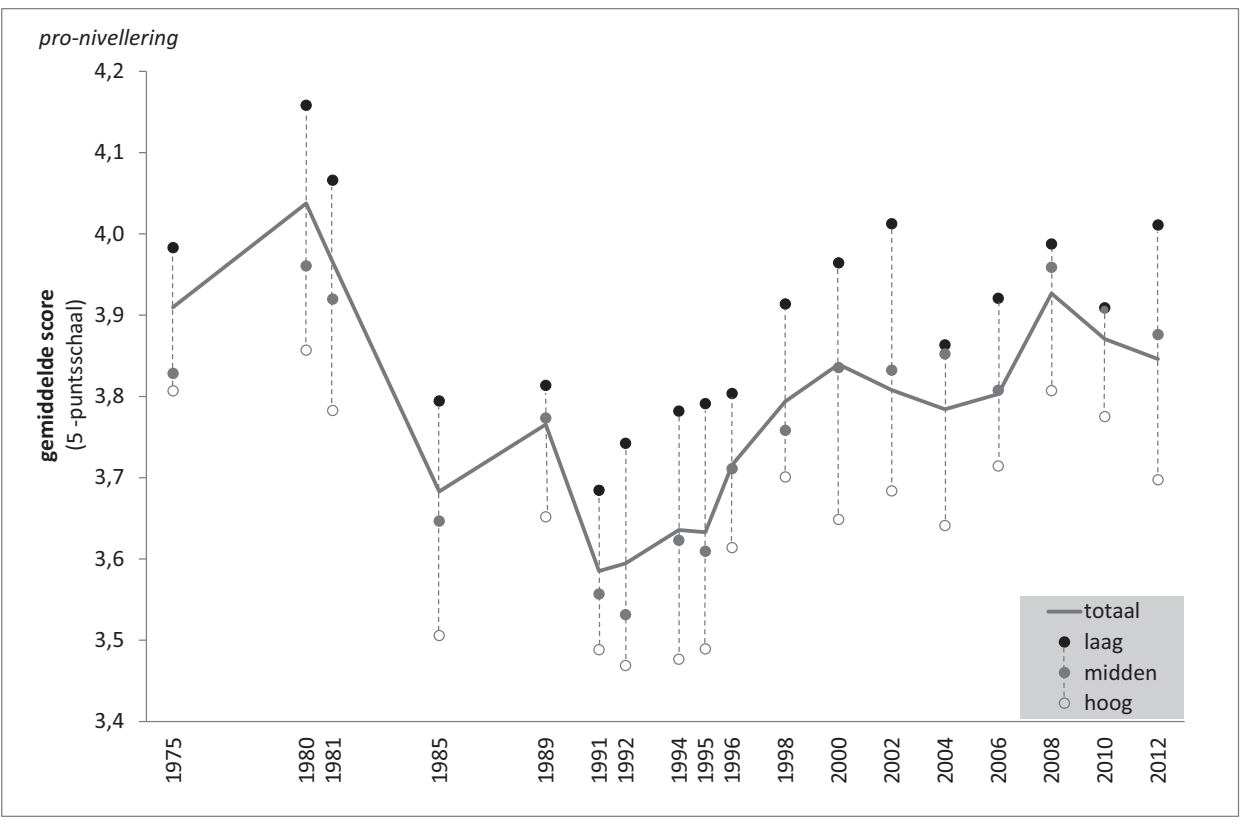

Figuur 3 Voorkeur voor inkomensnivellering, 1975-2012 (totaal en naar opleidingsniveau $)^{a}$

a 'Moeten de verschillen in inkomen veel groter worden, een beetje groter worden, hetzelfde blijven, een beetje kleiner worden of veel kleiner worden?'

Bron: SCP, Culturele Veranderingen in Nederland 1975-2012

In vrijwel alle jaren doen zich duidelijke contrasten voor tussen de laag- en hoogopgeleiden: hoe hoger de opleiding, des te minder weerstand tegen grotere inkomensverschillen. Dekker en Den Ridder (2014a, b) decomponeerden de gemiddelde scores in de jaren 1975 en 2012 naar opleidingsniveau. ${ }^{16}$ Op grond daarvan concludeerden zij dat het verschil tussen beide jaren zo beperkt bleef doordat de steun voor nivellering weliswaar groter werd bij de slinkende groep laagopgeleiden, maar dat dit werd gecompenseerd door minder weerstand tegen groeiende inkomensverschillen bij de groter wordende categorie hogeropgeleiden. Het is echter de vraag of dit de volledige verklaring is: de omkering van de trend in de jaren negentig laat zich niet goed herleiden tot veranderingen in de omvang en opvattingen van de opleidingsgroepen.

Wanneer we de veranderingen in de nivelleringsvoorkeur relateren aan de ontwikkeling van de feitelijke inkomensongelijkheid, dan blijkt het verband - de trendbreuk in het IPO buiten beschouwing latend - het sterkst met de spreiding in de primaire inkomens. Dat is niet verrassend, want 
theoretisch zou men op grond van de median voter-hypothese ook verwachten dat het inkomen vóór herverdeling bepalend is voor de opvattingen. Een oplopende ongelijkheid in de bruto inkomens gaat echter niet samen met meer steun voor nivellering, zoals die hypothese veronderstelt, maar met een groter draagvlak voor denivellering ( $r=-0,69$ à -0,73, afhankelijk van de gebruikte ongelijkheidsmaatstaf). Mogelijk kan dit worden verklaard door de werking van andere factoren. Daarbij valt te denken aan institutionele veranderingen in het hybride Nederlandse sociale zekerheidsregime, de daaraan gekoppelde opvattingen over solidariteit en rechtvaardigheid bij elkaar opvolgende generaties, veranderingen in het welvaartspeil, de economische conjunctuur of de afnemende uitkeringsafhankelijkheid bij niet-gepensioneerden (zie verder Arts \& Gelissen, 2001; Blekesaune, 2007; Dallinger, 2010; Jaeger, 2006; Svallfors, 2010; Vrooman, 2012b).

\section{Conclusies en discussie}

Welk inkomensbegrip men ook hanteert, en welke ongelijkheidsmaatstaf men ook kiest: er is geen sprake van dat de inkomensongelijkheid de laatste decennia voortdurend afnam. De voornaamste voorspelling van Ganzeboom en Ultee (1996) kwam dus niet uit. Integendeel: in de periode 20012012 zien we bij het primaire, en in mindere mate het bruto, inkomen enige polarisatie optreden. Ook al namen we die tendens in de jaren negentig en voorbijgaand aan de trendbreuk in het Inkomenspanelonderzoek - niet waar, dit biedt toch enige steun voor de stellingname van Salverda (2014). Bij het besteedbaar inkomen dat mensen daadwerkelijk ontvangen liep de ongelijkheid in het nieuwe millennium minder sterk op, en is de verandering als we vanaf 1990 kijken gering. Dat maakt de conclusie van Caminada e.a. (2014a, 2015) en het CBS (2014) dat het inkomensbeeld overwegend stabiel is eveneens verdedigbaar.

Uit de decompositie die we voor het besteedbaar inkomen uitvoerden blijkt dat in de periode 2003-2012 de ongelijkheid niet verminderde door veranderingen in het onderwijsniveau. Dat kwam ook al naar voren in de analyse die Pommer e.a. (2003) voor de jaren negentig uitvoerden. De beschikbare gegevens zijn bij dit kenmerk in beide studies beperkter dan bij de andere decomposities. Anders dan Ganzeboom en Ultee (1996) veronderstelden lijkt het er echter niet op dat afnemende verschillen in het bereikte onderwijsniveau via cohortvervanging hebben doorgewerkt in minder grote inkomenstegenstellingen. Veranderingen naar etnische her- 
komstgroep hadden evenmin veel invloed op de inkomensverdeling, doordat de veel zwaarder wegende groep autochtonen de ontwikkeling goeddeels bepaalt. Wijzigingen bij het aantal verdieners en de inkomensbronnen bleken wel stuwende krachten. Van de door Dessens (1996) voorspelde ongelijkheidstoename door de groei van het tweeverdienerschap (+15 procent) is iets minder dan de helft gerealiseerd. Dat gebeurde echter uitsluitend in het nieuwe millennium; en niet alleen doordat bij paren het eenverdienerschap steeds meer de uitzondering op de regel werd, maar ook door verdunning en diversificatie van huishoudens. Het aandeel armere alleenstaanden groeide van 2001 op 2012, terwijl de welvarende groep tweeverdieners groter en rijker werd. De minder welvarende alleenverdieners werden een marginale categorie, waarvan het gemiddeld inkomen over de gehele periode terugliep. Veranderingen naar inkomensbron hadden volgens de decompositie echter de meest uitgesproken effecten. In de jaren negentig daalde de inkomensongelijkheid licht vanwege gemiddeld lagere winstinkomens aan de top en hogere pensioenen aan de onderkant. Van 2001 op 2012 steeg ze met zes à zeven procent, doordat er meer winstontvangers en gepensioneerden kwamen, en minder loontrekkenden. Die toename werd deels tenietgedaan door de gemiddeld lagere winsten en hogere pensioenen.

Terugblikkend over de periode 1975-1994 zag Hermkens (1996) een autonome trend in de steun voor inkomensnivellering: deze nam onder de bevolking steeds verder af. Als dit zou doorzetten kon men verwachten dat de groep voorstanders in 2012 twee vijfde kleiner zou zijn geworden. Achteraf blijkt 1991 echter een keerpunt te zijn geweest, dat Hermkens in zijn kortere tijdreeks nog niet kon waarnemen. Na dat jaar nam de steun voor inkomensnivellering overwegend toe; en ook deze verwachting is dus niet uitgekomen. Dat geldt eveneens voor de aan de median voter-theorie ontleende hypothese dat het draagvlak voor nivellering toeneemt als de inkomensongelijkheid groeit. Gedurende de afgelopen decennia was het verband in Nederland precies andersom.

Vastgesteld kan dus worden dat de inkomensvoorspellingen van Ganzeboom en Ultee, met inbegrip van de bijdragen van Dessens en Hermkens aan die studie, goeddeels niet zijn uitgekomen. De belangrijkste reden lijkt dat de gekozen theoretische basis vrij smal was, al hebben beperkingen in de destijds beschikbare gegevens zeker ook een rol gespeeld. Vanuit de moderniseringstheorie lag het voor de hand de voornaamste drijvende kracht achter de inkomensongelijkheid te zoeken in de voortgezette meritocratisering van het onderwijs, en de gevolgen die de voortgaande emancipatie van vrouwen zou hebben voor hun arbeidsdeelname en de huis- 
houdensinkomens. Daarmee liet men echter een aantal grote veranderingen naar inkomensbron en bij de niet-paren buiten beschouwing: de groei van de zelfstandigen zonder personeel, de combinatie van vergrijzing en verbeterende pensioenen met een grotere dekkingsgraad, en de huishoudensverdunning en -diversificatie. Op de eerste ontwikkeling na was dit alles destijds wel te voorzien geweest. Het is achteraf eveneens opmerkelijk dat Hermkens concludeerde dat de autonome trend in de opvattingen over nivellering geen verdere verklaring behoefde. Dit had ook als een theoretische uitdaging kunnen worden opgevat; en dat geldt des te meer nu de tendens achteraf bezien juist in de jaren negentig blijkt te zijn omgeslagen. Wellicht kan een uitgebreider decompositie-analyse dan Dekker en Den Ridder (2014a, 2014b) onlangs verrichtten (met meer variabelen en tussenliggende meetpunten) hier meer licht op werpen.

Over de hier gehanteerde methoden kan worden opgemerkt dat het bij de analyse van inkomensongelijkheid valt aan te bevelen de verdelingen eerst gedetailleerd 'met het blote oog' te bekijken (vergelijk figuur 1). Op die manier krijgt men een indruk van de veranderingen op verschillende posities van de inkomensverdeling, en van de invloed van eventuele trendbreuken. De veelgebruikte Gini-maatstaf heeft beperkingen, vanwege de geringe gevoeligheid voor veranderingen aan de uiteinden van de verdeling. De hier gebruikte alternatieve maatstaven, de Theilcoëfficiënt en de gemiddelde logdeviatie, vormen daarom een nuttige aanvulling. Ze leiden echter niet tot wezenlijk andere conclusies over de ongelijkheidstrends voor en na de eeuwwisseling, al zijn die soms wel meer geprononceerd (zie figuur 2). Gezamenlijk geven de drie maatstaven een redelijk compleet beeld. De twee alternatieven hebben bovendien als voordeel dat ze eenvoudig decomponeerbaar zijn, waardoor de invloed van de onderliggende veranderingen in de omvang en gemiddelde inkomens van maatschappelijke groepen duidelijk worden. Aan een decompositiebenadering kleven echter ook beperkingen. Zo blijven de causale mechanismen tussen de variabelen impliciet, en krijgt men geen zicht op leeftijd-, periode- en cohorteffecten. Het is daarom wenselijk in de toekomst ook een uitgebreider en meer theoretisch gestuurde modelmatige benadering van inkomensongelijkheid te overwegen. Dat kan bijvoorbeeld via een cross-classified random effects multiniveaumodel, waarin ook de LPCeffecten een plaats krijgen (Rabe-Hesketh \& Skrondal, 2008; Jiang \& Carriere, 2014). Geavanceerde regressiebenaderingen van inkomensongelijkheid kunnen echter problematisch zijn, onder andere vanwege de gevoeligheid van de uitkomsten voor de gekozen modelspecificatie (Cowell \& Fiorio, 2009). 
Voor het beleid is van belang dat de inkomensongelijkheid in Nederland naar internationale verhoudingen niet groot is, en sinds 1990 weliswaar niet afnam, maar ook niet sterk steeg. Dit kwam eveneens naar voren in de recente landenvergelijkende analyse van Atkinson (2015: 22, 26, 64, 81), zeker waar Nederland wordt afgezet tegen de Verenigde Staten en het Verenigd Koninkrijk. Er is in ons land wel sprake van een groeiend en goed gedocumenteerd armoedeprobleem, vooral bij grote (eenouder)gezinnen, bijstandontvangers en niet-westerse migranten (SCP/CBS, 2014). Ook hangt rond een dee ${ }^{17}$ van de kleine groep met extreem hoge inkomens en vermogens, en rond de veelverdieners in de publieke sector, inmiddels een zweem van onrechtvaardigheid. In de studie van Ganzeboom en Ultee zag men dit reeds aan komen - al doen de voorbeelden die daarin van 'graaiers' werden genoemd naar de hedendaagse standaard nogal onschuldig aan. ${ }^{18}$ De tegenstelling tussen degenen die op rozen en zij die op zwart zaad zitten is zeer bepalend voor de maatschappelijke beeldvorming, en niet louter symbolisch. Wel dient men te bedenken dat de groep met de allerhoogste inkomens klein is. De huishoudens van de 100 topmannen in het bedrijfsleven die bruto soms 'meer dan honderd keer zoveel verdienen als hun werknemers' ( $€ 441.000$ á $€$ 24,2 miljoen volgens de Volkskrant, 20 juni 2015) maken slechts één duizendste procent uit van het bevolkingstotaal. ${ }^{19}$ Daardoor legt deze categorie in ongelijkheidsmaatstaven niet veel gewicht in de schaal, en is de kans dat ze in een steekproef belandt klein.

Ganzeboom en Ultees voorspelling over het grote belang dat rond de derde dinsdag van september 2015 zou worden gehecht aan 'koopkrachtplaatjes of versies hiervan' is zoals verwacht uitgekomen. Men kan overigens verdedigen dat juist dit politieke ritueel heeft bijgedragen aan vrij stabiele inkomensverhoudingen. Toch zouden inkomenstegenstellingen, vanwege het vrij lage ongelijkheidsniveau en de beperkte veranderingen die we hier hebben gevonden, niet de centrale kwestie in het actuele Nederlandse debat over sociale verschillen moeten zijn. Zoals aangegeven in het Sociaal en Cultureel Rapport 2014 (Vrooman et al., 2014: 331-342) kan men zich daarin beter richten op meer urgente vraagstukken: maatschappelijke tegenstellingen in termen van etnische herkomst, gezondheid en aantrekkelijkheid; de gescheiden leefwerelden van hoog- en laagopgeleiden; politieke onvrede; en de kloof tussen de machtselite en de rest van de bevolking. 


\section{Noten}

1. Salverda (2014) baseerde zich hierbij hoofdzakelijk op veranderingen in de bruto-inkomensverdeling. Hij trekt ook conclusies over wijzigingen in de ongelijkheid in marktinkomen (exclusief overdrachtsinkomens), besteedbaar (na correctie voor heffingen en premies) en gestandaardiseerd besteedbaar inkomen (idem, gecorrigeerd voor huishoudensomvang). Die zijn echter niet als zelfstandige verdelingen geanalyseerd, maar uitgesplitst naar decielen van het bruto inkomen.

2. De Gini-coëfficiënt is gevoelig voor veranderingen in het middengebied van de inkomensverdeling, en mist daardoor volgens Salverda (2014) een deel van de door hem gesignaleerde trends, hetgeen de tamelijk stabiele waarden zou verklaren.

3. Dit hangt af van het gekozen startjaar. Tussen 1975 en 1980 liep het aandeel mensen dat voor inkomensnivellering is vrij sterk op, van 62 naar 69 procent. Een regressie over de gehele periode 1975-1994 levert een structurele daling met één procent op. Indien 1975 buiten beschouwing wordt gelaten is in de meeste jaren sprake van een daling (of een kleine positieve verandering) en bedraagt de geschatte autonome trend $-1,5$ procent.

4. Ganzeboom en Ultees 'wanprestatiebelasting' is nooit ingevoerd, maar er is via o.a. de Tabaksblat-regels (opgevolgd door de Corporate Governance Code, 2012) en de Balkenendenorm (uitgebreid in de Wet normering topinkomens, 2012) wel getracht de groei van de allerhoogste inkomens in de private en (semi-)publieke sector te beteugelen.

5. Bij de revisie van het Inkomenspanelonderzoek is in 2000 de methode van ophogen herzien, waardoor de aansluiting op de Huishoudensstatistiek verbeterde. Door een afname van eenpersoons- en een toename van meerpersoonshuishoudens is het totaal aantal huishoudens na de trendbreuk lager. Ook zijn de indelingen naar de samenstelling van het huishouden en de voornaamste inkomensbron van het huishouden aangepast. Bij het laatste zijn mensen zodra sprake is van inkomen uit onderneming als zodanig geclassificeerd, ook als de looninkomsten hoger waren. Hierdoor daalt logischerwijs het aantal mensen met looninkomsten, terwijl de groep met winst groter wordt. Op de totale inkomensongelijkheid is dit niet van invloed. Verder worden na de trendbreuk meer kleinere vermogensinkomsten waargenomen. Daardoor zijn er ook meer mensen met een positief primair inkomen (de groep zonder loon of winst, maar met zulke vermogensinkomsten). Ten slotte is de huurwaarde anders berekend (van bruto naar netto: afschrijvingen worden verdisconteerd) en zijn in de nieuwe reeks pensioenpremies en pseudopremies van ambtenaren toegevoegd aan de primaire en bruto inkomens. Het laatste heeft een vrij aanzienlijk effect, vooral bij de hogere inkomens; dit beïnvloedt de verdeling van het besteedbaar inkomen voor en na de trendbreuk logischerwijs echter niet, want daar zijn de desbetreffende premies weer afgetrokken. De mate van waargenomen herverdeling wordt na de trendbreuk door deze aanpassing wel groter, want het verschil tussen primaire/bruto inkomens en besteedbare inkomens neemt toe. Indelingen naar kenmerken van het hoofd zijn na de trendbreuk vervangen voor die van de hoofdkostwinner (degene met het hoogste persoonlijk inkomen). Het CBS heeft voor 2000 een IPO-bestand beschikbaar waarin de trendbreuk is verwerkt, maar dat heeft vijftien jaar na dato nog steeds een voorlopige status. Zie verder Salverda (2012: 89-94) en CBS (2015).

6. Het primair inkomen bestaat uit het inkomen uit arbeid, winst en vermogen, met inbegrip van fiscale aftrekposten en vrijstellingen. Daartoe behoort ook de hypotheekrenteaftrek (negatieve vermogensinkomsten). Bij het bruto inkomen zijn hieraan toegevoegd de ontvangen overdrachten, zoals socialezekerheidsuitkeringen, aanvullende 
pensioenen en gebonden uitkeringen (bijvoorbeeld tegemoetkoming studiekosten, huurtoeslag). Door de betaalde premies en belastingen hier van af te trekken verkrijgt men het besteedbaar inkomen. Sommige posten, zoals kinderalimentatie, overdrachten tussen familieleden, eenmalige bijzondere bijstand en (kwijtschelding van) lokale heffingen worden in het Inkomenspanelonderzoek niet waargenomen; zie CBS (2015) voor een uitgebreide beschrijving. Alle analyses zijn verricht over de ongestandaardiseerde inkomens; er is dus niet gecorrigeerd voor het aantal huishoudensleden en schaalvoordelen bij grotere huishoudens. De invloed van de huishoudenssamenstelling op de ongelijkheid in het besteedbaar inkomen komt bij de decompositie echter wel aan de orde.

7. De Lorenzcurve is een grafische weergave van ongelijkheid. Op de x-as staat de bevolking naar inkomen gerangschikt, de y-as toont de cumulatieve inkomensaandelen. Een ongelijke inkomensverdeling neemt dan de vorm aan van een kromme, terwijl een $45^{\circ}$ lijn perfecte gelijkheid aangeeft (waarbij iedere waarneming evenveel inkomen ontvangt). Naarmate de Lorenzcurve verder van de lijn van perfecte gelijkheid af ligt, is de ongelijkheid groter. De Ginicoëfficiënt is gelijk aan de oppervlakte tussen de Lorenzcurve en de $45^{\circ}$-lijn, gedeeld door de totale oppervlakte onder de $45^{\circ}$-lijn.

8. Na correctie voor de toename van het totale aantal huishoudens en prijsveranderingen (beide in het peil van 2012) groeide de groep met een primair huishoudensinkomen van $€$ 100.000-200.000 van 578.00o huishoudens in 2001 naar 761.000 in 2012. Dit is een stijging van 7,7 naar 10,2 procent van alle huishoudens. De omvang van de groep met een inkomen van $€ 200.000$ of meer liep op van 71.000 naar 91.00o. Dat laatste is 1,2 procent van alle huishoudens in 2012.

9. De negatieve inkomens die na selectie van het onderste percentiel nog resteerden zijn op nul gesteld. Voor de primaire inkomens betreft dat 3,5-6\% van de resterende waarnemingen, voor de bruto en besteedbare inkomens is het nihil. Bij het primair inkomen is per definitie sprake van een grote groep nulinkomens (zie figuur 1), waarvan de omvang van jaar tot jaar wisselt. Omdat het logaritme van nul oneindig is zijn bij de berekening van de MLD de nulinkomens op een gesteld (in de calculatie van de Theilcoëfficiënt staat de vermenigvuldiging met het inkomensaandeel voor deze groep bij conventie op nul). Dat blijkt echter sterk van invloed op de waarde van deze indicator, en daarom is die in figuur 2 bij het primair inkomen niet opgenomen. De inkomens aan de bovenkant zijn door ons ongemoeid gelaten, maar het CBS past in het IPO soms wel 'top coding' toe. Inkomen uit eigen onderneming is afgekapt op een miljoen euro, inkomen uit aanmerkelijk belang op $€ 250.000$.

10. In 2007 werd de belasting op het aanmerkelijk belang tijdelijk verlaagd. In reactie daarop hebben directeur-grootaandeelhouders vaker dan in andere jaren vanuit hun BV dividenduitkeringen gedaan of aanmerkelijk belangaandelen verkocht. Dit komt dat jaar tot uiting in inkomensstijgingen aan de top.

11. Dit verklaart ook de vrij grote verschillen tussen de gemiddelde logdeviatie en de Theilcoëfficiënt in de jaren negentig. Vanaf 2001 doen die zich niet voor, omdat het aandeel negatieve en nulinkomens na de eerder besproken selectie (zie noot 9) nihil is.

12. Soede e.a. (2014) wijzen bij de hogere inkomens echter wel op enkele tegenstrijdige bewegingen. Het besteedbaar huishoudensinkomen op het niveau van het goe percentiel liep tussen 2001 en 2012 met zeven procent op, en dat van het 99e percentiel met negen procent; het mediane inkomen was na correctie voor de inflatie vrijwel stabiel. Die groeiende inkomenstegenstellingen 'pal onder de top' schrijven zij toe aan de toename van het aandeel zelfstandigen, een groep waarbij de onderlinge inkomensverschillen groot zijn. Echter, deze oplopende inkomensverschillen boven de mediaan 
werden volgens Soede e.a. (2014) tenietgedaan doordat de inkomensgrens van de bovenste 0,1 procent in deze periode met een kwart daalde, vooral omdat de groep met vermogen als belangrijkste inkomensbron kleiner werd.

13. Van tweeverdienerschap is hier sprake als in een paar het belastbaar inkomen van beide partners afzonderlijk ongelijk is aan nul; dit kan dus ook inhouden dat één van hen (of beiden) een negatief inkomen heeft.

14. Wel valt op dat van 1990 op 2000 de tekens van de Theilcoëfficiënt en de gemiddelde logdeviatie bij het aandeel en het gemiddeld inkomen in de decompositie tegengesteld zijn $(-2 /+2$ en $+6 /-6)$. Enkele simulaties leren dat dit komt door verschillen die inherent zijn aan de maatstaven. Bij de Theilcoëfficiënt wordt gewogen met het aandeel van iedere waarneming in het totale inkomen, waardoor veranderingen bij hogere inkomens relatief zwaar meetellen (die hebben immers een groter aandeel). Bij de MLD vindt geen weging plaats; maar omdat deze maatstaf uitgaat van het logaritme van het inkomen werken veranderingen aan de bovenkant minder zwaar door, en die aan de onderkant juist zwaarder.

Tussen 1990 en 2000 deden zich bij het aantal verdieners de volgende ontwikkelingen voor (zie tabel $\mathrm{A} \mathbf{i}$ in de appendix):

a. er kwamen meer alleenstaanden/overigen, en hun gemiddeld inkomen steeg. Deze categorie verkeert aan de onderkant, waardoor de grotere omvang tot meer ongelijkheid leidt en het stijgend inkomen dit doet afnemen (een verhoudingsgewijs arme groep wordt groter maar minder arm);

b. de groep eenverdieners werd kleiner en zag het gemiddeld inkomen dalen. Deze categorie zit boven het algemeen gemiddelde. De ongelijkheid daalt vanwege de veranderingen in omvang en gemiddeld inkomen (een vrij rijke groep wordt kleiner en wat minder rijk);

c. er kwamen meer tweeverdieners en hun gemiddeld inkomen nam fors toe. Deze categorie bevindt zich aan de bovenkant van de inkomensverdeling. De omvangs- en inkomenseffecten vergroten beide de ongelijkheid (een rijke groep wordt groter en beduidend rijker).

Bij de MLD domineren de ontwikkelingen bij de armste groep, de alleenstaanden/ overigen (a), en de coëfficiënten weerspiegelen dat: denivellering vanwege hun grotere omvang, nivellering vanwege hun stijgende inkomen. In de decompositie op basis van de Theilcoëfficïent zijn vooral de ontwikkelingen bij de hogere inkomensgroepen (b en c) bepalend. Die werken tegengesteld in op de inkomensongelijkheid: de veranderingen bij de eenverdieners zijn nivellerend, die bij de tweeverdieners denivellerend. Dat verklaart waarom de procentuele veranderingen lager zijn dan bij de MLD. Per saldo domineert bij de omvang de sterke daling van het aandeel eenverdieners (dalende ongelijkheid) en bij het gemiddeld inkomen de toename onder tweeverdieners (stijgende ongelijkheid).

In de decomposities van de andere variabelen doen zich bij de Theilcoëfficiënt en de MLD niet zulke contraire effecten voor. Dat komt doordat de categorieën met een verhoudingsgewijs hoog of laag inkomen (zoals winstontvangers of werklozen) veel kleiner zijn, of minder grote wijzigingen doormaken. Veranderingen aan de extremen van de inkomensverdeling werken dan minder sterk door in de waarde van de coëfficiënten.

15. De weerstand tegen groeiende inkomensongelijkheid is overigens wat groter dan die tegen grotere vermogensverschillen (Soede e.a., 2014).

16. Over deze lange periode bezien is de verdeling naar opleiding in Culturele Veranderingen in Nederland van jaar op jaar niet altijd goed vergelijkbaar. Dat komt door verande- 
ringen in het onderwijsstelsel, aanpassingen van de vragenlijst en steekproeffluctuaties. Zo neemt bij de driedeling die wij hanteren het aandeel hoogopgeleiden van $2000 \mathrm{op}$ 2002 sterk toe (van 19 naar $3^{1}$ procent) en dat van laagopgeleiden navenant af, en fluctueert het aandeel laagopgeleiden tussen 2002 en 2012 tussen de 18 en 32 procent. Om die reden dichotomiseerden Dekker en de Ridder (2014a, b) de opleidingsvariabele in hoog versus laag opgeleid.

17. Soede e.a. (2014) wijzen erop dat de rechtvaardigheidsperceptie van grote vermogens samenhangt met de bron ervan. Indien mensen hun vermogen verwierven via een succesvol eigen bedrijf of een erfenis, wordt dat rechtvaardiger geacht dan wanneer ze hun rijkdom als soapacteur of beroepsvoetballer vergaarden.

18. Ganzeboom en Ultee (1996: 341) achtten het destijds mogelijk dat er publieke discussies zouden ontstaan over 'een gouden handdruk voor een hoofdcommissaris van politie, een wethouder die wist van onwetmatige vetlozingen en de boete die 'zijn' gemeente moet betalen, en het college van bestuur van een universiteit dat niet goed oplette bij het afsluiten van een collectieve ziektekostenverzekering'.

19. Uitgedrukt als aandeel van alle 1,4 miljoen bedrijven en instellingen die Nederland in 2014 telde gaat het om zeven duizendste, en wanneer we daar de ruim 800.000 zelfstandigen zonder personeel van aftrekken om 16 duizendste procent. Dat is dus nog steeds verwaarloosbaar (en inkomensongelijkheid wordt gewoonlijk afgemeten aan de verdeling over personen of huishoudens, niet bij bedrijven en instellingen).

\section{Referenties}

Arts, W. \& Gelissen, J. (2001). Welfare states, solidarity and justice principles: Does the type really matter? Acta Sociologica, 44, 283-299.

Atkinson, A.B. (2015). Inequality: What can be done? Cambridge, MA: Harvard University Press.

Autor, D.H. \& Dorn, D. (2013). The growth of low skill service jobs and the polarization of the U.S. labor market. American Economic Review, 103, 1553-1597.

Bavel, B. van (2014). Vermogensongelijkheid in Nederland; De vergeten dimensie. In: M. Kremer, M. Bovens, E. Schrijvers \& R. Went (Red.), Hoe ongelijk is Nederland? Een verkenning van de ontwikkeling en gevolgen van economische ongelijkheid (pp. 79-10o). Den Haag: Wetenschappelijke Raad voor het Regeringsbeleid.

Berg, A. van den \& Hartog, J. (1999). Honderd jaar ongelijkheid; Inkomensverschillen sinds het einde van de negentiende eeuw. In: R. van der Bie \& P. Dehing (Red.), Nationaal goed: Feiten en cijfers over onze samenleving ca. $1800-1999$ (pp. 109-124). Voorburg: Centraal Bureau voor de Statistiek.

Blekesaune, M. (2007). Economic conditions and public attitudes towards welfare policies. European Sociological Review, 23, 393-403.

Caminada, K., Been, J., Goudswaard, K. \& Graaf-Zijl, M. de (2014a). De ontwikkeling van inkomensongelijkheid en inkomensherverdeling in Nederland 1990-2012. Leiden: Universiteit van Leiden.

Caminada, K., Goudswaard, K. \& Knoef, M. (2014b). Vermogen in Nederland gelijker verdeeld sinds eind 19 eeuw. Me Judice, 27 juni (www.mejudice.nl/artikelen/detail/vermogen-in-nederland-gelijker-verdeeld-sinds-eind-negentiende-eeuw).

Caminada, K., Goudswaard, K. \& Knoef, M. (2015). Belasting aan de top: geen spoor van groeiende ongelijkheid. Me Judice, 14 maart (www.mejudice.nl/artikelen/detail/belasting-aan-de-topgeen-spoor-van-groeiende-ongelijkheid). 
CBS (2014). Welvaart in Nederland 2014. Den Haag: Centraal Bureau voor de Statistiek.

CBS (2015). Documentatierapport Inkomenspanelonderzoek 2013. Den Haag: Centraal Bureau voor de Statistiek.

Cowell, F.A. \& Fiorio, C.V. (2009). Inequality decomposition - a reconciliation. London: London School of Economics/STICERD.

Cowell, F.A. \& Flachaire, E. (2002). Sensitivity of inequality measures to extreme values. London: London School of Economics/STICERD.

Dallinger, U. (2010). Public support for redistribution: What explains cross-national differences? Journal of European Social Policy, 20, 333-349.

Dekker, P. \& Ridder, J. den (2014a). Polariseert Nederland? Ontwikkelingen in politiek-culturele tegenstellingen. In: M. Bovens, P. Dekker \& W. Tiemeijer (Red.). Gescheiden werelden? Een verkenning van sociaal-culturele tegenstellingen in Nederland (pp. 103-130). Den Haag: Sociaal en Cultureel Planbureau/Wetenschappelijke Raad voor het Regeringsbeleid.

Dekker, P. \& Ridder, J. den (2014b). Het politiek-culturele verschil. In: C. Vrooman, M. Gijsberts \& J. Boelhouwer (Red.) (2014). Verschil in Nederland - Sociaal en Cultureel Rapport 2014 (pp. 178202). Den Haag: Sociaal en Cultureel Planbureau.

Dessens, J. (1996). Inkomensongelijkheid van huishoudens; verwachte ontwikkelingen op basis van gegevens in de periode 1979-1991. In: H.B.G. Ganzeboom \& W.C. Ultee (Red.). De sociale segmentatie van Nederland in 2015 (pp. 49-68). Den Haag: Wetenschappelijke Raad voor het Regeringsbeleid/Sdu Uitgevers.

Dronkers, J. \& Ultee, W.C. (1995). Verschuivende ongelijkheid in Nederland; Sociale gelaagdheid en mobiliteit. Assen: Van Gorcum.

Ganzeboom, H.B.G. \& Ultee, W.C. (Red.) (1996). De sociale segmentatie van Nederland in 2015. Den Haag: Wetenschappelijke Raad voor het Regeringsbeleid/Sdu Uitgevers.

Graaf-Zijl, M. de, Josten, E., Boeters, S., Eggink, E., Bolhaar, J., Ooms, I., Ouden, A. den \& Woittiez, I. (2015). De onderkant van de arbeidsmarkt in 2025. Den Haag: Centraal Planbureau en Sociaal en Cultureel Planbureau.

Hacker, J. (2011). The institutional foundations of middle-class democracy. Policy Network (http:// www.policy-network.net/articles/3998/The-institutional-foundations-of-middle-class-democracy).

Hartog, J. \& Veenbergen, J.G. (1978). Dutch treat; Long-run changes in personal income distribution. De Economist, 126, 521-549.

Hermkens, P. (1996). Inkomensverdeling en rechtvaardiging van inkomensverschillen. In: H.B.G. Ganzeboom \& W.C. Ultee (Red.). De sociale segmentatie van Nederland in 2015 (pp. 303-332). Den Haag: Wetenschappelijke Raad voor het Regeringsbeleid/Sdu Uitgevers.

Jaeger, M.M. (2006). Welfare regimes and attitudes towards redistribution: The regime hypothesis revisited. European Sociological Review, 22, 157-170.

Jenkins, S.P. \& Kerm, Ph. van (2009). The measurement of economic inequality. In: W. Salverda, B. Nolan \& T.M. Smeeding (Red.). The Oxford handbook of economic inequality. Oxford: Oxford University Press.

Jiang, B. \& Carriere, K.C. (2014). Age-period-cohort models using smoothing splines: a generalized additive model approach. Statistics in Medicine, 33, 595-606.

Josten, E., Vlasblom, J. \& Vrooman, C. (2014). Bevrijd of beklemd? Werk, inhuur, inkomen en welbevinden van zzp'ers. Den Haag: Sociaal en Cultureel Planbureau.

Katz, L.F. \& Murphy, K.M. (1992). Changes in relative wages, 1963-1987: Supply and demand factors. The Quarterly Journal of Economics, 107, 35-78.

Kremer, M., Bovens, M., Schrijvers, E. \& Went, R. (Red.) (2014). Hoe ongelijk is Nederland? Een verkenning van de ontwikkeling en gevolgen van economische ongelijkheid. Den Haag: Wetenschappelijke Raad voor het Regeringsbeleid. 
Meltzer, A.H. \& Richard, S.F. (1981). A rational choice theory of the size of government. Journal of Political Economy, 89, 914-927.

Mookherjee, D. \& Shorrocks, A.F. (1982). A decomposition analysis of the trend in UK income inequality. Economic Journal, 92, 886-902.

Piketty, Th. (2014). Capital in the twenty-first century. Cambridge, MA/London: The Belknap Press of Harvard University Press.

Pommer, E., Leeuwen, J. van \& Ras, M. (2003). Inkomen verdeeld; Trends in ongelijkheid, herverdeling en dynamiek. Den Haag: Sociaal en Cultureel Planbureau.

Pouwels-Urlings, N. \& Brakel, M. van den (2014). Vermogensongelijkheid tijdens de crisis. Economisch Statistische Berichten, 99, 396-398.

Rabe-Hesketh, S. \& Skrondal, A. (2008). Multilevel and longitudinal modeling using Stata. College Station: Stata Press.

Roine, J. \& Waldenström, D. (2014). Long-run trends in the distribution of income and wealth. Bonn: Institute for the Study of Labor|IZA.

Salverda, W. (2013). Inkomen, herverdeling en huishoudvorming 1977-2011: 35 jaar ongelijkheidsgroei in Nederland. TPEdigitaal, $7,66-94$.

Salverda, W. (2014). De tektoniek van de inkomensongelijkheid in Nederland. In: M. Kremer, M. Bovens, E. Schrijvers \& R. Went (Red.), Hoe ongelijk is Nederland? Een verkenning van de ontwikkeling en gevolgen van economische ongelijkheid (pp. 39-58). Den Haag: Wetenschappelijke Raad voor het Regeringsbeleid.

Salverda, W., Haas, C., Graaf-Zijl, M. de, Lancee, B., Notten, N. \& Ooms, T. (2013). GINI country report: Growing inequalities and their impacts in the Netherlands (http://www.gini-research. org/system/uploads/512/original/Netherlands.pdf?1380138293)

SCP/CBS (2014). Armoedesignalement 2014. Den Haag: Sociaal en Cultureel Planbureau.

Shorrocks, A.F. (1980). The class of additively decomposable inequality measures. Econometrica, $48,613-625$.

Shorrocks, A.F. (1984). Inequality decomposition by population subgroups. Econometrica, 52, 1369-1385.

Soede, A., Hoff, S. \& Kullberg J. (m.m.v. J.M. Wildeboer Schut) (2014). Kapitale tegenstellingen? De maatschappelijke betekenis van financiële ongelijkheid. In: C. Vrooman, M. Gijsberts \& J. Boelhouwer (Red.), Verschil in Nederland - Sociaal en Cultureel Rapport 2014 (pp. 103-138). Den Haag: Sociaal en Cultureel Planbureau.

Stiglitz, J.E. (2012). The price of inequality. New York /London: W.W. Norton \& Company.

Svallfors, S. (2010). Public attitudes. In: F.G. Castles, S. Leibfried, J. Lewis, H. Obinger \& C. Pierson (Red.), The Oxford handbook of the welfare state (pp. 241-251). Oxford: Oxford University Press.

Theil, H. (1967). Economics and information theory. Amsterdam: North-Holland.

Vrooman, C. (2012a). Een succesvolle gedaantewisseling? De hervorming van de sociale zekerheid, 1985-2010. Tijdschrift voor Arbeidsvraagstukken, 25, 358-377.

Vrooman, J.C. (2012b). Regimes and cultures of social security: Comparing institutional models through nonlinear PCA. International Journal of Comparative Sociology, 53, 444-477.

Vrooman, C., Gijsberts, M. \& Boelhouwer, J. (Red.) (2014). Verschil in Nederland - Sociaal en Cultureel Rapport 2014. Den Haag: Sociaal en Cultureel Planbureau.

Vrooman, C. \& Wildeboer Schut, J.M. (2013). Het karige bestaan; Een kwart eeuw armoede in Nederland. TPEdigitaal, 7, 27-50.

Wilterdink, N. (1984). Vermogensverhoudingen in Nederland: Ontwikkelingen sinds de negentiende eeuw. Amsterdam: De Arbeiderspers. 


\section{Over de auteurs}

Cok Vrooman is hoofd van de sector Arbeid en Publieke Voorzieningen van het Sociaal en Cultureel Planbureau, en bijzonder hoogleraar Sociale Zekerheid en Participatie aan de Universiteit Utrecht, afdeling Sociologie. Zijn onderzoek richt zich op arbeidsmarkt- en sociale zekerheidsvraagstukken, armoede, ongelijkheid, sociale uitsluiting en comparatieve institutionele analyses.

Postadres: Sociaal en Cultureel Planbureau, Postbus 16164, 2500 BD Den Haag.

E-mail: c.vrooman@scp.nl

Jean Marie Wildeboer Schut is wetenschappelijk medewerker bij de sector Arbeid en Publieke Voorzieningen van het Sociaal en Cultureel Planbureau. Hij is gespecialiseerd in inkomensvraagstukken.

Postadres: Sociaal en Cultureel Planbureau, Postbus 16164, 2500 BD Den Haag.

E-mail: j.wildeboer.schut@scp.nl 


\section{Appendix}

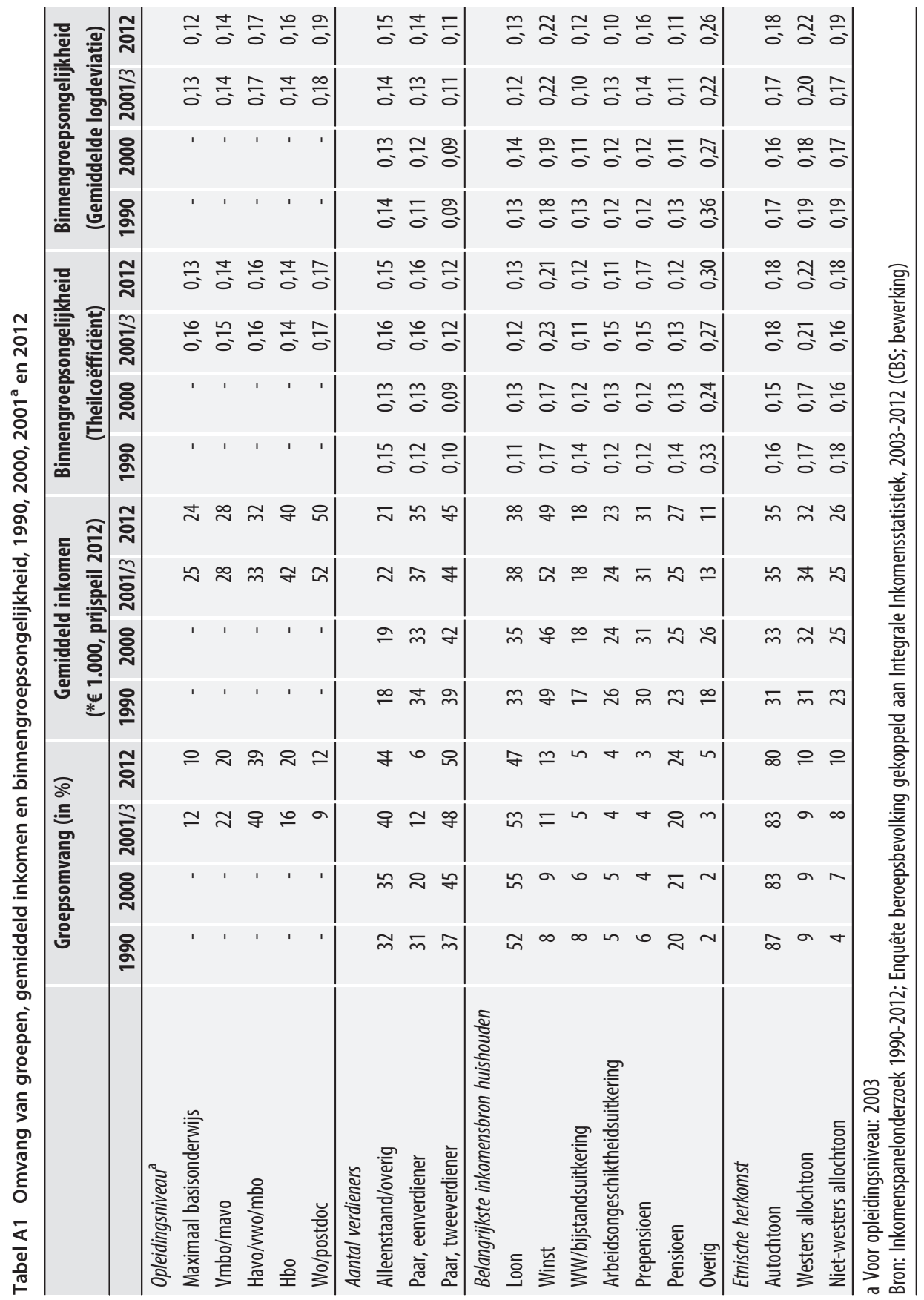

